\title{
Bowhead and Gray Whale Distributions, Sighting Rates, and Habitat Associations in the Eastern Chukchi Sea, Summer and Fall 2009-15, with a Retrospective Comparison to 1982-91
}

\author{
Janet T. Clarke, ${ }^{1}$ Amy S. Kennedy ${ }^{2}$ and Megan C. Ferguson ${ }^{3}$
}

(Received 22 October 2015; accepted in revised form 31 May 2016)

\begin{abstract}
We analyzed data from line-transect aerial surveys for marine mammals conducted in the eastern Chukchi Sea $\left(67^{\circ}-72^{\circ} \mathrm{N}, 157^{\circ}-169^{\circ} \mathrm{W}\right)$ in July to October of $2009-15$ to investigate bowhead and gray whale distributions, behaviors, sighting rates, and habitat selection preferences, the last of which allowed direct comparison with results from data collected in this area in 1982-91. Bowhead whales use the eastern Chukchi Sea primarily for migrating between the Beaufort Sea and the Bering Sea, while gray whales use the area to feed on locally abundant benthic amphipods and other prey. Bowhead whales were observed during all survey months and were distributed up to $300 \mathrm{~km}$ offshore west and southwest of Point Barrow, Alaska, but without a defined migratory corridor in either summer (July-August) or fall (September-October). Bowhead whale sighting rates (whales per km on effort) were highest in the shelf/trough (51-200 m North) depth zone in the northeastern Chukchi Sea in both summer and fall. This pattern was reflected in habitat selection ratios, which found bowhead whales in summer and fall selecting primarily shelf/trough habitat in the northeastern Chukchi Sea, with shelf habitat (36-50 m) being preferred secondarily. Gray whales were observed in all survey months and were distributed primarily within $\sim 95 \mathrm{~km}$ of shore between Point Barrow and Icy Cape in the northeastern Chukchi Sea, and about 60-115 km southwest of Point Hope in the southern Chukchi Sea. In both summer and fall, gray whale sighting rates and habitat selection ratios were highest in the shelf/trough (51-200 m South) depth zone in the southern Chukchi Sea. In the northeastern part of the study area, gray whale sighting rates and habitat selection ratios both identified coastal habitat $(\leq 35 \mathrm{~m})$ as preferred habitat in summer and shelf/trough (51-200 m North) as preferred habitat in fall. Distribution and habitat associations of bowhead and gray whales remained similar over the 34-year time span with one exception: gray whale preference for shelf/trough habitat in the southern Chukchi Sea is now evident throughout summer and fall, whereas three decades ago gray whale preference for that area was limited to fall only.
\end{abstract}

Key words: bowhead whale; Balaena mysticetus; gray whale; Eschrichtius robustus; Arctic; Chukchi Sea; habitat; aerial survey; feeding

RÉSUMÉ. Nous avons analysé les données provenant de levés aériens par transects linéaires à l'égard de mammifères marins, levés effectués dans l'est de la mer des Tchouktches $\left(67^{\circ}-72^{\circ} \mathrm{N}, 157^{\circ}-169^{\circ} \mathrm{O}\right)$ d'octobre à juillet 2009 à 2015 afin de prélever des données sur la répartition des baleines boréales et des baleines grises, sur leurs comportements, sur leurs taux d'observation et sur leurs préférences en matière d'habitat. Ce dernier élément nous a permis de faire des comparaisons directes avec les résultats de la collecte de données effectuée dans cette région entre 1982 et 1991. Les baleines boréales se servent principalement de l'est de la mer des Tchouktches pour migrer entre la mer de Beaufort et la mer de Béring, tandis que les baleines grises empruntent cette région pour se nourrir des amphipodes benthiques qui y abondent ainsi que d'autres proies. Des baleines boréales ont été observées pendant tous les mois visés par les levés, et celles-ci étaient réparties sur une distance allant jusqu'à $300 \mathrm{~km}$ au large, à l'ouest et au sud-ouest de Point Barrow, en Alaska, sans toutefois emprunter un couloir migratoire particulier à l'été (juillet et août) ou à l'automne (septembre et octobre). Les taux d'observation de baleines boréales (nombre de baleines par km à l'effort) étaient plus élevés dans la zone de profondeur de plateformes et de dépressions (de 51 à $200 \mathrm{~m}$ nord) faisant partie du nord-est de la mer des Tchouktches, tant à l'été qu'à l'automne. Cette tendance se reflète dans les rapports de sélection d'habitats, selon lesquels les baleines boréales choisissent principalement, l'été et l'automne, un habitat de plateformes et de dépressions dans le nord-est de la mer des Tchouktches, l'habitat des plateformes (de 36 à $50 \mathrm{~m}$ ) constituant une préférence secondaire. Des baleines grises ont été observées pendant tous les mois visés par les levés. Elles se répartissaient principalement à l'intérieur de $\sim 95 \mathrm{~km}$ de la côte, entre Point Barrow et Icy Cape, dans le nord-est de la mer

\footnotetext{
${ }^{1}$ Corresponding author: Leidos, 4001 N. Fairfax Dr., Arlington, Virginia 22203, USA; janet.clarke@leidos.com

${ }^{2}$ Joint Institute for the Study of the Atmosphere and Ocean, University of Washington, 3737 Brooklyn Ave NE, Seattle, Washington 98195, USA; amy.kennedy@noaa.gov

${ }^{3}$ Cetacean Assessment and Ecology Program, Marine Mammal Laboratory, Alaska Fisheries Science Center, National Marine Fisheries Service, National Oceanic and Atmospheric Administration, 7600 Sand Point Way NE, Seattle, Washington 98115, USA; megan.ferguson@noaa.gov

(C) The Arctic Institute of North America
} 
des Tchouktches, et à environ 60 à $115 \mathrm{~km}$ au sud-ouest de Point Hope, dans le sud de la mer des Tchouktches. Tant à l'été qu'à l'automne, les taux d'observation et les rapports de sélection d'habitats des baleines grises étaient à leur point le plus élevé dans la zone de profondeur des plateformes et des dépressions (de 51 à $200 \mathrm{~m}$ sud) du sud de la mer des Tchouktches. Dans le secteur nord-est de la région visée par l'étude, les taux d'observation et les ratios de sélection d'habitats des baleines grises ont tous deux permis d'affirmer que l'habitat côtier $(\leq 35 \mathrm{~m})$ était l'habitat préféré pendant l'été, et que l'habitat des plateformes et des dépressions (de 51 à $200 \mathrm{~m}$ nord) était l'habitat préféré à l'automne. Les associations en matière de répartition et d'habitat des baleines boréales et des baleines grises sont demeurées semblables au cours de la période de 34 ans, à une exception près : la préférence de la baleine grise pour l'habitat des plateformes et des dépressions dans le sud de la mer des Tchouktches est maintenant évidente à l'été et à l'automne, tandis qu'il y a trois décennies, la préférence de la baleine grise pour cet habitat se limitait à l'automne.

Mots clés : baleine boréale; Balaena mysticetus; baleine grise; Eschrichtius robustus; Arctique; mer des Tchouktches; habitat; levé aérien; alimentation

Traduit pour la revue Arctic par Nicole Giguère.

\section{INTRODUCTION}

Physical and biological changes over the past decade have given rise to a "new state" in the Pacific Arctic region (Wood et al., 2015). One of the most visible changes has been the drastic reduction in summer sea ice extent and volume throughout the Arctic, which has intensified in the Chukchi and Beaufort Seas since 2000 (Frey et al., 2015). This change has reduced or altered the habitat available for marine mammals dependent on sea ice for foraging and resting, which include ice seals (Laidre et al., 2008, 2015), walruses (Jay et al., 2012), and polar bears (Derocher et al., 2004; Gleason and Rode, 2009; Rode et al., 2013). The immediate impacts on cetaceans of sea ice loss and other changing environmental parameters associated with the "new" Arctic (Jeffries et al., 2013) may not be observable or may be less dramatic (Moore and Huntington, 2008; Kovacs et al., 2011), and long-term impacts are unknown. Several large cetacean species occur seasonally in the Alaskan Arctic (Clarke et al., 2013a), but only the bowhead whale (Balaena mysticetus) and gray whale (Eschrichtius robustus) routinely migrate in large numbers into the Chukchi Sea.

The spring migration of the Bering-Chukchi-Beaufort Sea stock of bowhead whales passes through nearshore leads in the ice between Point Hope and Point Barrow, Alaska, in the northeastern Chukchi Sea (Moore and Reeves, 1993). Although bowhead whales have been documented in the Chukchi Sea throughout summer (Moore, 1992; Moore et al., 2010), and were common there prior to commercial whaling (Bockstoce and Burns, 1993), their presence in the Chukchi Sea in summer has been described as rare (Dahlheim et al., 1980; Miller et al., 1986; Hannay et al., 2013). Most bowhead whales spend summer and early fall in the Beaufort Sea, feeding primarily on copepods and euphausids in areas of upwelling that occur annually near Cape Bathurst and Tuktoyaktuk Peninsula (Citta et al., 2015) and at several locations in the Alaskan Beaufort Sea (Clarke et al., 2015). Bowhead whales migrate west across the Alaskan Beaufort Sea and northeastern Chukchi Sea in late summer and fall. Moore (2000) and
Moore et al. (2000) described distribution and habitat use for the period 1982-91. Additional information about bowhead whale fall migration comes from satellite tagging data (2006-12; 54 whales tagged; Citta et al., 2015) and passive acoustic monitoring results (2007-11; Delarue et al., 2009; Hannay et al., 2013), which show that bowhead whales followed both a west-northwesterly route along the continental slope and a broad southwesterly route towards the Chukotka coast.

The Eastern North Pacific stock of gray whales migrates each year between winter breeding grounds near Baja California, Mexico, and summer feeding areas in the Bering and Chukchi Seas (Rugh et al., 1999). Gray whales were commonly sighted in the northeastern Chukchi Sea in summer and fall during aerial surveys conducted from 1982 to 1991 (Moore et al., 2000). Recent evidence indicates that feeding gray whales may now be more common in the Chukchi Sea than in the Chirikov Basin in the northern Bering Sea, in part because amphipod biomass has decreased in the latter area (Moore et al., 2003; Coyle et al., 2007; Bluhm and Gradinger, 2008). However, sightings of large groups of feeding gray whales in September 2014 (Ferguson et al., 2015) suggest that gray whale occurrence in the Chirikov Basin may vary considerably from year to year.

Broad-scale aerial surveys, funded by the Minerals Management Service (MMS; now the Bureau of Ocean Energy Management, BOEM) were conducted from 1982 to 1991 in the northern Bering, eastern Chukchi, and western Beaufort Seas (Moore, 2000; Moore et al., 2000). From 1992 to 2007, MMS-sponsored aerial surveys continued to be conducted in the western Beaufort Sea (e.g., Monnett and Treacy, 2005), but few aerial surveys (e.g., Thomas et al., 2010) and no broad-scale surveys took place in the eastern Chukchi Sea. In 2008, MMS and the National Marine Fisheries Service (NMFS) reinstated aerial surveys in the eastern Chukchi Sea as part of the Aerial Surveys of Arctic Marine Mammals (ASAMM) project. ASAMM, like its precursors, is designed to document the distribution and relative abundance of marine mammals and monitor areas of importance for specific behaviors, such as calving, pupping, feeding, hauling out, and migrating. ASAMM surveys 
are of particular relevance because of renewed interest in oil and gas exploration and production in the northeastern Chukchi Sea (Minerals Management Service, 2008), and they provide a unique opportunity to compare cetacean habitat use over a span of more than 30 years. Although ASAMM surveys extend into the western Beaufort Sea (e.g., Clarke et al., 2015), this paper is limited to the eastern Chukchi Sea because that is the area where bowhead and gray whale distributions overlap.

We present information about bowhead and gray whale distributions, sighting rates, and habitat preferences from data collected during aerial surveys conducted in the eastern Chukchi Sea in summer and fall from 2009 to 2015. We also reanalyzed historical data collected during MMSsponsored aerial surveys conducted from 1982 to 1991, originally analyzed in Moore et al. (2000), to directly compare depth zone and sea ice habitat selection over a three decade time span. Belugas, included in Moore et al. (2000), were not included here because of the relative lack of sightings in the Chukchi Sea.

\section{METHODS}

\section{9-15 Survey Effort, Sighting Distributions, Sighting Rates, and Habitat Selection}

The study area in the eastern Chukchi Sea extended from $67^{\circ} \mathrm{N}$ to $72^{\circ} \mathrm{N}$ and from $157^{\circ} \mathrm{W}$ to $169^{\circ} \mathrm{W}$, an area totaling $155500 \mathrm{~km}^{2}$ that comprises the western portion of the ASAMM survey area (Fig. 1) and overlies most of the active leases from BOEM Lease Sale 193 (U.S. DOI, 2011). This area provided the best comparison between recent $(2009-15)$ and historical $(1982-91)$ bowhead and gray whale data and generally coincides with the Chukchi Sea study area of Moore et al. (2000) although the latter extended to the Bering Strait, outside of the current ASAMM study area. Surveys were flown from July to October in Turbo Commanders (2009-15) and de Havilland Twin Otters (2009). All survey aircraft were outfitted with bubble windows to permit detection of marine mammals directly under the aircraft. Line-transect aerial surveys were flown at 305 to $460 \mathrm{~m}$ altitude, maintaining a survey speed of approximately $220 \mathrm{~km} / \mathrm{h}$. Transects were spaced $19 \mathrm{~km}$ apart and oriented perpendicular to shore to sample across isobaths, prevailing currents, and expected gradients in marine mammal density. A new set of transects was generated for each year of the study, and within each year, selection of transects to be flown was based on getting the best representative coverage of the entire study area. A coastal transect between Point Barrow and Point Hope was also flown each year $1 \mathrm{~km}$ offshore and parallel to the coast.

The survey protocols described here for the 2009-15 period were similar to those used in the historical surveys conducted from 1982 to 1991 (although see the Discussion for exceptions). Two primary observers, one on each side of the aircraft, maintained a continuous watch for marine mammals while a third observer/data recorder entered data into a computer for each sighting, whenever survey conditions changed, or every five minutes. Sightings made by primary observers on transect were considered on-effort because primary observers were always actively searching on transect and systematic transect coverage incorporated effort in all depth (and sea ice) habitats without bias toward or against areas with the highest likelihood of sightings. The aircraft made brief $(<10$ minutes $)$ diversions from transects to circle whale sightings to identify sightings to species, estimate group size, and search for calves. Subsequent sightings made during circling were also considered on-effort, and a continuously updated map display on an onboard laptop computer ensured that duplicate sightings were not recorded during circling. Transits between targeted survey areas or transects, or survey effort along transect lines when weather was too poor for visual observations, were recorded as off-effort. Sightings from nonprimary observers (e.g., data recorder, pilots) were not included in analyses.

Data routinely logged when whales were seen included time, altitude, latitude, longitude, sea state, sea ice type and percent cover, visibility conditions, species, declination angle (to determine distance from the transect line), number of whales, number of calves, and the whales' initial heading and behavior. Behavioral classifications included swim, dive, feed, mill, mate, rest, and several types of displays. Bowhead whale feeding was inferred when whales were observed diving repeatedly in a fixed area, with mud on the snout or streaming from the mouth, exhibiting synchronous diving and surfacing, swimming in echelon formation at the surface, or swimming at the surface with mouth open. Gray whale feeding was recorded whenever conspicuous mud plumes were observed streaming out of the mouths of surfacing gray whales, an indication of benthic feeding. Swimming direction, which may indicate migratory behavior, was calculated using headings of bowhead and gray whales that were recorded during swimming behavior to yield a mean vector heading and circular standard deviation per season, using Oriana statistical software (Rayleigh Test; KCS, 2012). Sea state was classified according to the Beaufort scale (Maloney, 2006), and ice cover was estimated as a percentage of the sea surface visible to observers. Data were not collected when Beaufort Sea State was greater than 5 or ceilings were less than $305 \mathrm{~m}$. Additional details of survey protocol are provided elsewhere (e.g., Clarke et al., 2015).

Sighting rates (whales per $\mathrm{km}$ on effort) were calculated for each depth zone to examine monthly relative densities of bowhead and gray whales. Total on-effort distance (transect and circling-on-transect kilometers) per depth zone was calculated by clipping the transect lines to polygons defined by isobaths, using ESRI ArcGIS version 10.1. Sighting rates can be considered a measure of relative density because they were not corrected for availability or perception bias (Buckland, 2001); absolute density cannot be calculated at this time because trackline detection probability for these 


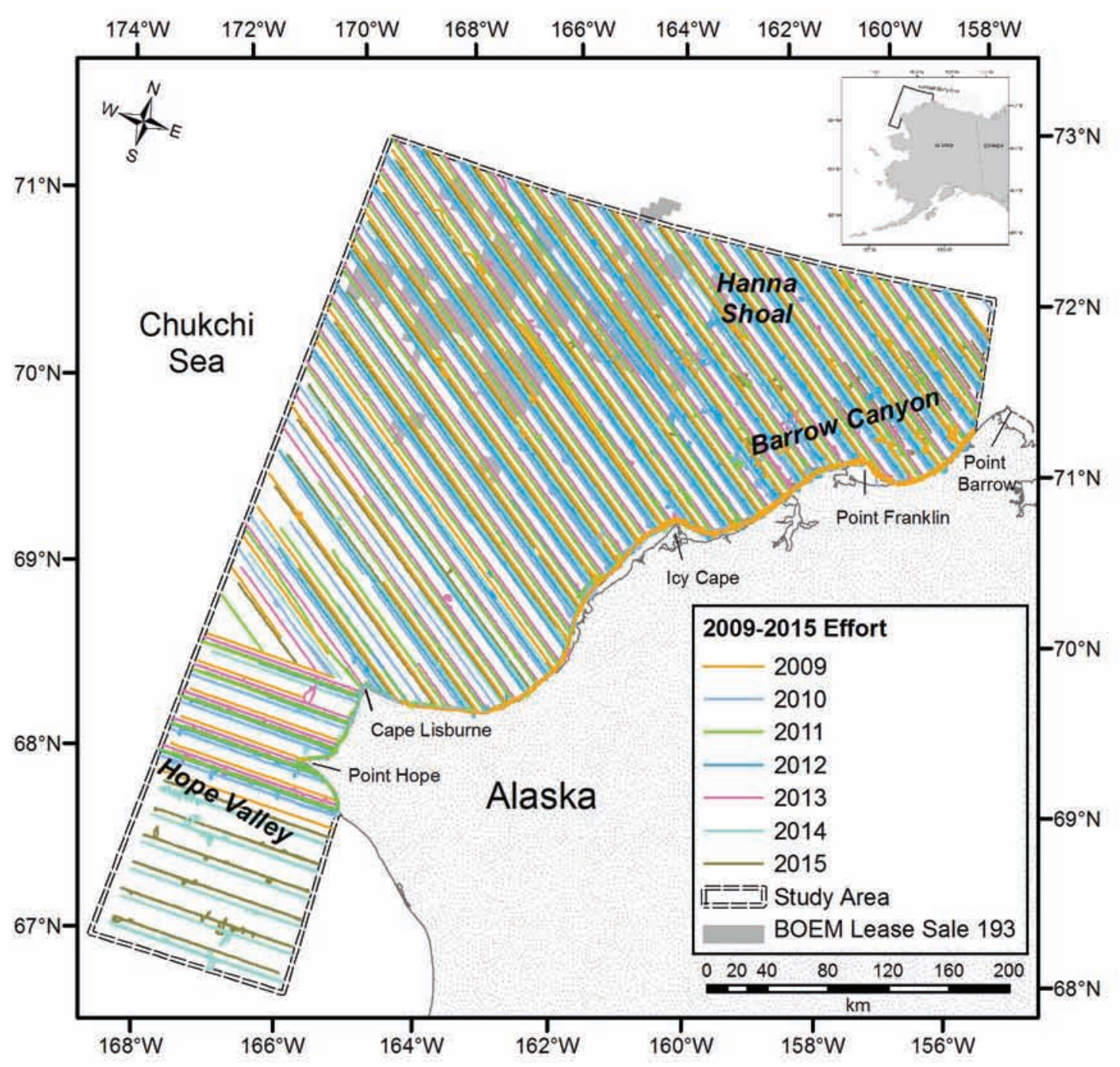

FIG. 1. Eastern Chukchi Sea study area and transect survey effort, 2009-15. Inset shows entire ASAMM study area in relation to the eastern Chukchi Sea study area.

surveys is unknown. All on-effort sightings from primary observers were used in analyses regardless of sea state, sea ice cover, or other environmental variables because these variables have not been shown to affect bowhead or gray whale detection probabilities on ASAMM surveys (Ferguson and Clarke, 2013).

Depth zones followed Moore et al. (2000) as closely as possible, and correspond to broad patterns of Pacific water masses in the Chukchi Sea (Weingartner et al., 2005). Four depth zones were identified:

1) Coastal/shoal. This zone is $\leq 35 \mathrm{~m}$ deep, encompassing the comparatively fresh Alaska Coastal Water, with some influence from the more saline Bering Sea Water. It accounts for $17 \%$ of the total study area.

2) Continental shelf. This zone is $36-50 \mathrm{~m}$ deep, encompassing Bering Sea Water, with some influence from Alaska Coastal Water. It includes Hanna Shoal and accounts for $65 \%$ of the total study area.
3) Shelf/trough North. This zone is $51-200 \mathrm{~m}$ deep and includes Barrow Canyon. It accounts for $10 \%$ of the total study area.

4) Shelf/trough South. This zone is $51-200 \mathrm{~m}$ deep and includes Hope Valley. It accounts for $8 \%$ of the total study area.

Shelf/trough was divided into North and South because this depth zone was not contiguous and incorporated distinct ecosystems (Bluhm et al., 2007). Depth zone isobaths were digitally derived and based on depth data in the International Bathymetric Chart of the Arctic Ocean (IBCAO) Version 2.23 (Jakobsson et al., 2008), which had a pixel resolution of $2 \mathrm{~km}$.

Calculation of habitat selection ratios also followed Moore et al. (2000). Microsoft Excel CHITEST was used to calculate chi-squared goodness-of-fit statistics (Manly et al., 2002) to determine whether whale distribution was proportional to survey effort for each depth zone in summer (July-August) and fall (September-October) seasons, using 
the numbers of observed and expected on-effort whales, where observed is the number of whales observed per depth zone and expected is the number of whales per depth zone if whale distribution were uniform. Habitat selection ratios $\left(\mathrm{w}_{i}\right)$ provide indices of habitat selection comparable between species and seasons (see Moore et al., 2000; Manly et al., 2002). These ratios were calculated as:

$$
\mathrm{W}_{i}=\mathrm{o}_{i} / \pi_{i}
$$

where $\mathrm{o}_{i}=$ proportion of whales observed in depth zone $i$, and $\pi_{i}=$ proportion of effort $(\mathrm{km})$ in depth zone $i\left(\pi_{i}\right.$ was identified as $\mathrm{pE} i$ in Moore et al., 2000). If $\mathrm{w}_{i}$ is greater than 1 , the proportion of whales in depth zone $i$ is greater than expected given the proportion of effort in depth zone $i$. If $\mathrm{W}_{i}$ is less than 1, the proportion of whales in depth zone $i$ is less than expected given the proportion of effort in depth zone $i$. The probability that a randomly selected whale would be in depth zone $i$ if there were equal survey effort across all depth zones could be computed by standardizing the selection ratios, assuming that individual whales were independently distributed. However, feeding whales tend to be aggregated into groups and cow-calf pairs are found in close association with each other, so the assumption of independence does not hold. Therefore, we did not compute standardized habitat selection ratios. Habitat selection ratios were calculated using the package "adehabitatHS" (version 0.3.9; Calenge, 2006, 2011) of software R (version 3.2.3; R Core Team, 2015).

\section{Habitat Selection Comparison, 1982-91 and 2009-15}

To compare habitat selection by bowhead and gray whales observed in the eastern Chukchi Sea in 1982-91 with that observed in 2009-15, we used a subset of data selected to ensure that as many variables as possible were equivalent between the two time periods. Direct comparison of bowhead and gray whale sighting rates from 1982 to 1991 and 2009 to 2015 is not possible because of differences in survey platform and data collection protocols, which likely affect detection probabilities, and which are detailed in the Discussion. Bowhead and gray whale sighting rates from 1982 to 1991 were not reanalyzed. However, habitat selection ratios using whales and effort on transect from 1982-91 and 2009-15 allow for determination of habitat preferences within each time period and comparison of these preferences between time periods. Data from 1982-91 were reanalyzed using number of whales rather than number of sightings to better incorporate multianimal groups, including cow-calf pairs and feeding groups, and depth zones were based on the same digitally derived depth contours described above. Geographic, temporal, and depth zone parameters remained the same as described above. However, circling effort and primary observers were not recorded in the 1982-91 Chukchi Sea data. Therefore, for the habitat selection comparison between historical and recent data, effort in both 1982-91 and 2009-15 was limited to transect effort only, and sightings from all observers were used to determine the number of whales. Sea ice habitat selection in 1982-91 and 2009 - 15 was also compared, using the same sea ice categories as in Moore et al. (2000): open water/light $(0 \%-10 \%)$, light/moderate $(11 \%-40 \%)$, moderate/heavy $(41 \%-70 \%)$, and heavy $(71 \%-100 \%)$. Total on-effort distance (transect kilometers) was calculated by summing the total effort per sea ice category using ESRI ArcGIS version 10.1.

\section{RESULTS}

\section{9-15 Survey Effort, Sighting Distribution, and Sighting Rates}

More than $177000 \mathrm{~km}$ were flown on-effort in the eastern Chukchi Sea from 2009 to 2015 (Fig. 1), with variation among years and months (Table 1, Fig. 2). Annual survey effort was greatest in 2012 (>30 $000 \mathrm{~km}$ ), when two dedicated aircraft were conducting surveys in early July (Fig. 2). Monthly effort across all years was highest in September $(>54000 \mathrm{~km}$ total; average $=7831 \mathrm{~km}$ per year) and lowest in October, when survey conditions in the Chukchi Sea often deteriorated $(<32000 \mathrm{~km}$; average $=4485 \mathrm{~km}$ per year). Nearly half $(46 \%)$ of total effort was in the continental shelf $(36-50 \mathrm{~m})$ depth zone (Table 1, Fig. 1), although this percentage was smaller than expected on the basis of relative area, assuming survey coverage was uniform throughout the study area.

There were 415 on-effort sightings of 566 bowhead whales in the eastern Chukchi Sea in 2009-15 (Table 1). Bowhead whales were seen during all survey months, with the greatest number of sightings and total whales in September (Table 1, Fig. 3B). There were relatively few sightings in July and August, despite more than $90000 \mathrm{~km}$ of effort. Locations of July sightings ranged from just west of Point Barrow to north and east of Cape Lisburne, while the distribution of the few bowhead whales observed in August was similar to that observed in fall months (Fig. 3A). In September and October, sightings were broadly distributed throughout the study area; distance from shore ranged from less than $1 \mathrm{~km}$ to $293 \mathrm{~km}$. Sighting rates were comparatively low in July and August, rose to 10 times as high in September, and were highest in October (Table 1). Sighting rate was highest in the shelf/trough North $(51-200 \mathrm{~m})$ depth zone in both summer and fall (Table 1). Bowhead whales were rarely seen south of $70^{\circ} \mathrm{N}$ (5 sightings of 5 whales), despite substantial effort.

Additional information about bowhead whale use of the eastern Chukchi Sea was obtained from the swim direction, behavior, and sea ice data. Most (74\%) bowhead whales were recorded as engaged in directional swimming, with a significant clustering around a mean heading of $266^{\circ}$ True bearing in fall (Rayleigh $\mathrm{Z}=7.542, p<0.0001$ ); swimming direction was not significantly clustered around a mean heading in summer. Feeding behavior was rarely recorded 
TABLE 1. Sightings of bowhead (top) and gray whales (bottom) in the eastern Chukchi Sea study area, 2009-15. Survey effort (km) includes kilometers flown on transect plus circling on transect. S (W) indicates number of sightings and (in parentheses) number of whales sighted. Sighting rate (SR), or number of whales per kilometer, is given for each depth zone in each month and season. Bold type indicates the maximum sighting rate for each season (for gray whales, in both north and south regions).

\begin{tabular}{|c|c|c|c|c|c|c|c|c|c|}
\hline \multirow[b]{2}{*}{ Bowhead whale: } & \multicolumn{3}{|c|}{ July } & \multicolumn{3}{|c|}{ August } & \multicolumn{3}{|c|}{ Summer } \\
\hline & $\mathrm{km}$ & $\mathrm{S}(\mathrm{W})$ & SR & $\mathrm{km}$ & $\mathrm{S}(\mathrm{W})$ & SR & $\mathrm{km}$ & $\mathrm{S}(\mathrm{W})$ & SR \\
\hline Coastal/Shoal $(\leq 35 \mathrm{~m})$ & 16803 & $8(12)$ & 0.0007 & 16201 & 0 & 0.0000 & 33004 & $8(12)$ & 0.0004 \\
\hline Continental Shelf $(36-50 \mathrm{~m})$ & 20372 & $6(8)$ & 0.0004 & 19689 & $8(12)$ & 0.0006 & 40061 & $14(20)$ & 0.0005 \\
\hline Shelf/Trough North (51-200 m North) & 8634 & $4(8)$ & 0.0009 & 7496 & $9(9)$ & 0.0012 & 16130 & $13(17)$ & 0.0011 \\
\hline Shelf/Trough South (51-200 m South) & 678 & 0 & 0.0000 & 1006 & 0 & 0.0000 & 1684 & 0 & 0.0000 \\
\hline Total & 46487 & $18(28)$ & 0.0006 & 44392 & $17(21)$ & 0.0005 & 90879 & $35(49)$ & 0.0005 \\
\hline \multicolumn{10}{|l|}{ Gray whale: } \\
\hline Coastal/Shoal $(\leq 35 \mathrm{~m})$ & 16803 & $249(490)$ & 0.0293 & 16201 & $104(166)$ & 0.0102 & 33004 & $353(656)$ & 0.0199 \\
\hline Continental Shelf $(36-50 \mathrm{~m})$ & 20372 & 94 (178) & 0.0087 & 19689 & $156(268)$ & 0.0136 & 40061 & $250(446)$ & 0.0111 \\
\hline Shelf/Trough North (51-200 m North) & 8634 & $64(106)$ & 0.0123 & 7496 & $86(130)$ & 0.0173 & 16130 & $150(236)$ & 0.0146 \\
\hline Shelf/Trough South (51-200 m South) & 678 & $25(48)$ & 0.0708 & 1006 & $54(102)$ & 0.1014 & 1684 & $79(150)$ & 0.0891 \\
\hline \multirow[t]{2}{*}{ Total } & 46487 & $432(822)$ & 0.0177 & 44392 & $400(666)$ & 0.0150 & 90879 & $832(1488)$ & 0.0164 \\
\hline & \multicolumn{3}{|c|}{ September } & \multicolumn{3}{|c|}{ October } & \multicolumn{3}{|c|}{ Fall } \\
\hline Bowhead whale: & $\mathrm{km}$ & $\mathrm{S}(\mathrm{W})$ & SR & $\mathrm{km}$ & $\mathrm{S}(\mathrm{W})$ & SR & $\mathrm{km}$ & $\mathrm{S}(\mathrm{W})$ & SR \\
\hline Coastal/Shoal $(\leq 35 \mathrm{~m})$ & 18220 & $17(25)$ & 0.0014 & 9155 & $9(9)$ & 0.0010 & 27375 & $26(34)$ & 0.0012 \\
\hline Continental Shelf $(36-50 \mathrm{~m})$ & 27075 & $91(123)$ & 0.0045 & 15103 & $78(92)$ & 0.0061 & 42178 & $169(215)$ & 0.0051 \\
\hline Shelf/Trough North (51-200 m North) & 8561 & $107(157)$ & 0.0183 & 6119 & $77(110)$ & 0.0180 & 14680 & $187(267)$ & 0.0182 \\
\hline Shelf/Trough South (51-200 m South) & 962 & $1(1)$ & 0.0010 & 1016 & 0 & 0.0000 & 1978 & $1(1)$ & 0.0005 \\
\hline Total & 54818 & $216(306)$ & 0.0056 & 31393 & $164(211)$ & 0.0067 & 86211 & $380(517)$ & 0.0060 \\
\hline \multicolumn{10}{|l|}{ Gray whale: } \\
\hline Coastal/Shoal $(\leq 35 \mathrm{~m})$ & 18220 & $14(22)$ & 0.0012 & 9155 & $10(12)$ & 0.0013 & 27375 & $24(34)$ & 0.0012 \\
\hline Continental Shelf $(36-50 \mathrm{~m})$ & 27075 & 92 (134) & 0.0049 & 15103 & $33(47)$ & 0.0031 & 42178 & $125(181)$ & 0.0043 \\
\hline Shelf/Trough North (51-200 m North) & 8561 & $38(55)$ & 0.0064 & 6119 & $13(16)$ & 0.0026 & 14680 & $51(71)$ & 0.0048 \\
\hline Shelf/Trough South (51-200 m South) & 962 & $87(138)$ & 0.1435 & 1016 & $5(14)$ & 0.0138 & 1978 & $92(152)$ & 0.0768 \\
\hline Total & 54818 & $231(349)$ & 0.0064 & 31393 & $61(89)$ & 0.0028 & 86211 & $292(438)$ & 0.0051 \\
\hline
\end{tabular}

(8 sightings of 25 whales); whales were noted as feeding in July of 2009 and 2012 and September of 2009, 2012, 2013, 2014, and 2015. Most feeding observations were relatively near shore $(<30 \mathrm{~km})$ between Point Barrow and Icy Cape; one pair of feeding bowhead whales was seen approximately $90 \mathrm{~km}$ northwest of Point Franklin in September 2015. Bowhead whales were seen in up to $80 \%$ broken floe sea ice, although most whales $(96 \%)$ were seen in the icefree conditions that were prevalent in late summer and fall in the study area.

There were 1124 on-effort sightings of 1926 gray whales in the eastern Chukchi Sea in 2009-15 (Table 1). Gray whales were seen during all survey months (Fig. 4), with the greatest number of sightings and total whales in July (Table 1). Gray whales were seen predominantly near shore $(<45 \mathrm{~km})$, with aggregations observed south and west of Barrow Canyon in the northeastern Chukchi Sea and offshore (up to $110 \mathrm{~km}$ ) in Hope Valley in the southern Chukchi Sea (Fig. 4). Because gray whales were found in these two distinct high-density regions at the northernmost and southernmost ranges in the study area, further discussion about gray whale sighting rates and habitat selection ratios will refer to the northeastern and southern Chukchi sea areas separately. Gray whales were seen south of Hanna Shoal (west of Barrow Canyon) primarily in late summer and early fall. Few gray whales were seen offshore elsewhere in the Chukchi Sea. In July and August, gray whales

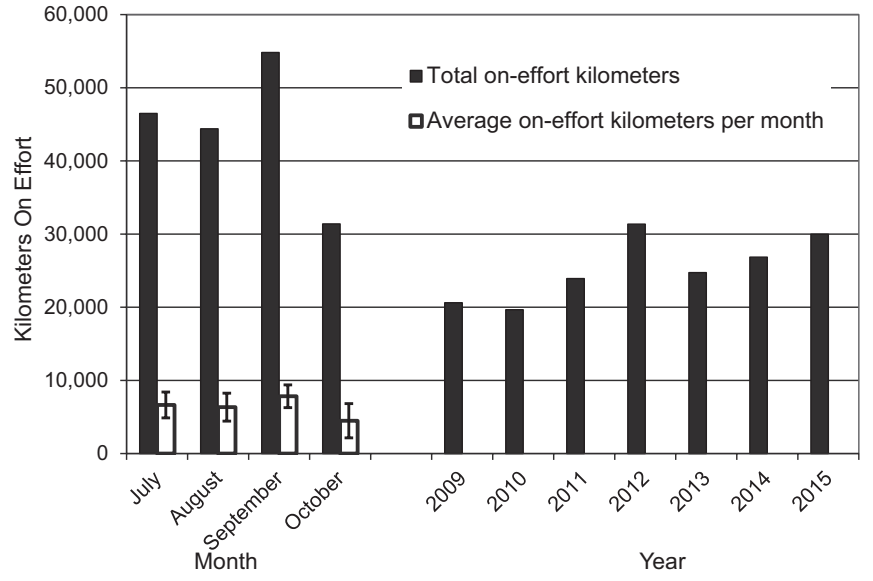

FIG. 2. Summary of on-effort kilometers flown during marine mammal aerial surveys in the eastern Chukchi Sea, July-October, 2009-15. Error bars represent one standard deviation of average on-effort kilometers per month.

were observed nearshore along the entire length of the eastern Chukchi coastline from Point Hope to Point Barrow, although areas of greatest sighting concentrations were offshore in Hope Valley and in the area between Icy Cape and Point Barrow (Fig. 4A). In September and October, relatively few gray whales were seen in shallow coastal waters except between Point Franklin and Point Barrow (Fig. 4B). Sighting rate was highest in July, decreased in August, and decreased significantly in September and October (Table 1). 

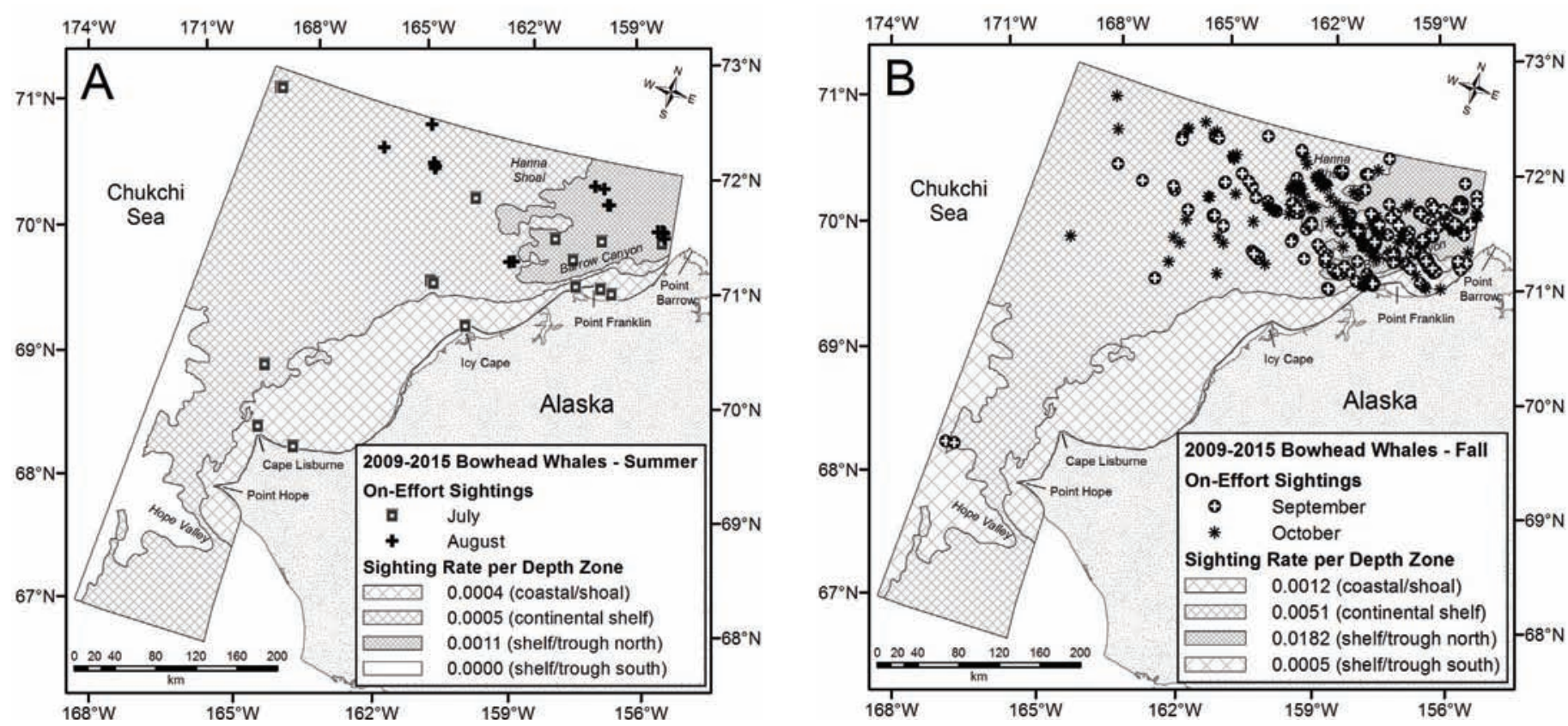

FIG. 3. On-effort bowhead whale sightings per month and sighting rate (whales per km) per depth zone, for (A) July and August and (B) September and October, 2009-15. Heavy shading represents highest sighting rate, and light shading, lowest sighting rate.

The highest sighting rate in summer was in the shelf/trough (51-200 m South) depth zone in the southern Chukchi Sea and the coastal/shoal $(\leq 35 \mathrm{~m})$ depth zone in the northeastern Chukchi Sea, while the highest sighting rates in fall were in the shelf/trough (51-200 m North and South) depth zones in both the southern and northeastern Chukchi Sea (Table 1). In the northeastern Chukchi Sea, sighting rates were highest in the coastal/shoal $(\leq 35 \mathrm{~m})$ depth zone only in July; in all other months, sighting rates were higher in shelf and shelf/trough ( $\geq 35 \mathrm{~m}$ ) depth zones (Table 1).

Gray whale swim direction was not significantly clustered around any heading in either summer or fall. Most gray whales were recorded as feeding (64\%), and feeding was observed in all survey months. Gray whales were seen in up to $80 \%$ broken floe ice, although most whales $(83 \%)$ were seen in the ice-free conditions that were present in late summer and throughout fall in the study area. Most $(90 \%)$ of the gray whales observed near sea ice were seen in July, when sea ice was still present in nearshore areas; gray whales were not observed near sea ice in offshore areas. The behavior of gray whales most often observed near sea ice was also feeding $(63 \%)$.

\section{9-15 Summer Habitat Selection}

Neither bowhead nor gray whales were distributed uniformly with respect to depth in summer (Table 2), although relatively few bowhead whales were seen $(n=49)$ so statistical significance of habitat selection is difficult to assess. Bowhead whales in summer preferred shelf/trough habitat (51-200 m North; $\left.\mathrm{w}_{i}=1.960\right)$ in the northeastern Chukchi Sea, with zero sightings in shelf/trough habitat in the southern Chukchi Sea and minimal preference for coastal/shoal
( $\leq 35 \mathrm{~m}$ depth) habitat $\left(\mathrm{w}_{i}=0.675\right.$; Table 3$)$. Gray whales in summer overwhelmingly preferred shelf/trough in the southern Chukchi Sea (51-200 m South; $\left.\mathrm{w}_{i}=5.316\right)$; in the northeastern Chukchi Sea, gray whales were more likely to use the coastal/shoal depth zone $\left(\leq 35 \mathrm{~m} ; \mathrm{w}_{i}=1.215\right)$ (Table 3).

Comparison of selection ratios between species indicated that bowhead whales selected deeper water habitat in the northeastern Chukchi Sea (51-200 m North) twice as often as gray whales, although caution should be taken interpreting these results because of the small number of bowhead whales seen in summer.

\section{9-15 Fall Habitat Selection}

Neither bowhead nor gray whales were distributed uniformly with respect to depth in fall (Table 2). Habitat selection ratios $\left(\mathrm{w}_{i}\right)$ showed that in fall, bowhead whales were more likely to be seen in shelf/trough (51-200 m North) habitat in the northeastern Chukchi Sea than in any other depth zone (Table 3). Bowhead whales used shelf/trough habitat $\left(\mathrm{w}_{i}=3.035\right)$ in the northeastern Chukchi Sea more than three times as frequently as continental shelf habitat $\left(36-50 \mathrm{~m} ; \mathrm{w}_{i}=0.851\right)$, and they almost never used coastal/shoal habitat $\left(\leq 35 \mathrm{~m} ; \mathrm{w}_{i}=0.208\right)$ or shelf/trough habitat in the southern Chukchi Sea (51-200 m South; $\mathrm{w}_{i}$ $=0.087)$ (Table 3). Gray whale habitat preference in fall remained overwhelmingly for shelf/trough habitat in the southern Chukchi Sea (51-200 m South; $\left.\mathrm{w}_{i}=15.087\right)$, and gray whales were least likely to use coastal/shoal habitat $\left(\leq 35 \mathrm{~m} ; \mathrm{w}_{i}=0.245\right)$.

Bowhead whales used deeper water habitat in the northeastern Chukchi Sea (51-200 m North) three times as 

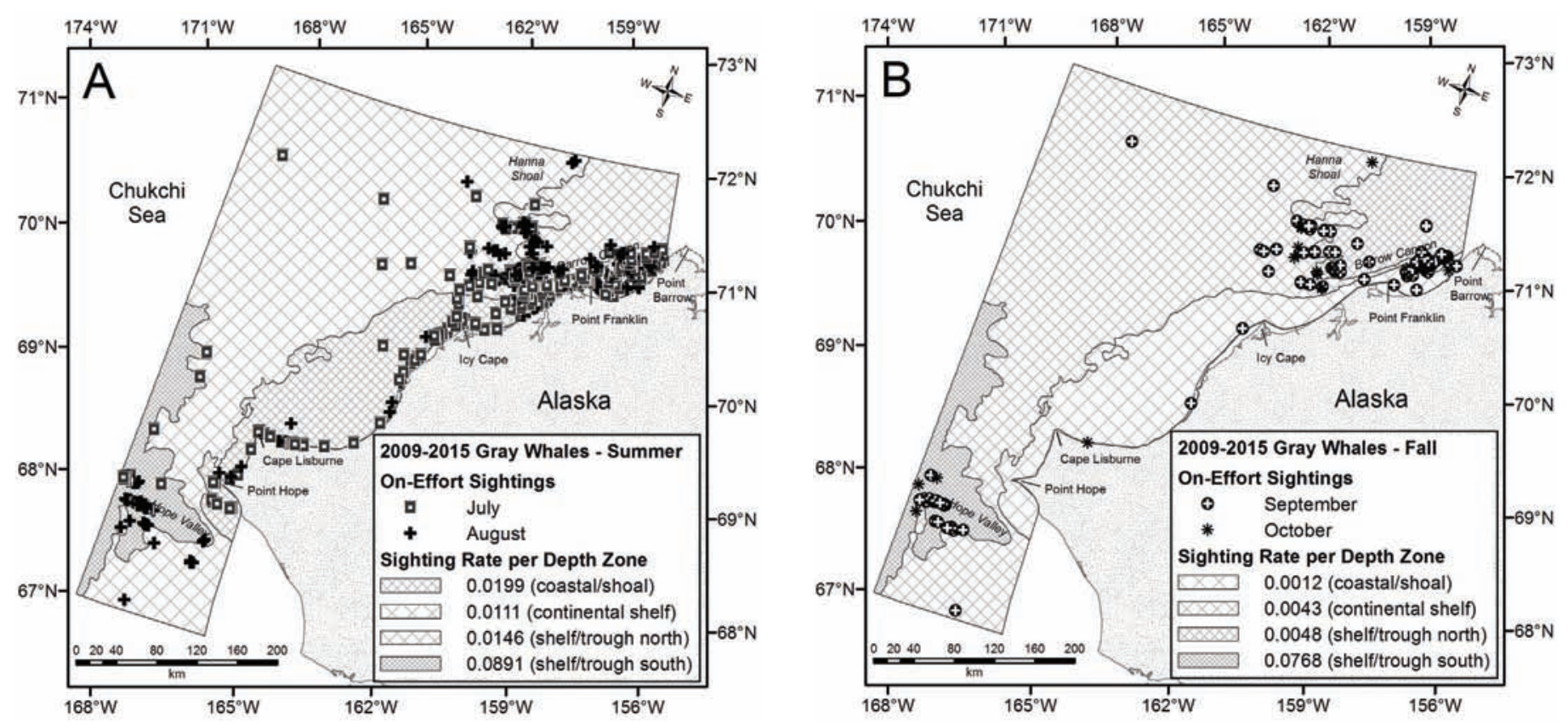

FIG. 4. On-effort gray whale sightings per month and sighting rate (whales per km) per depth zone, for (A) July and August and (B) September and October, $2009-15$. Heavy shading represents highest sighting rate, and light shading, lowest sighting rate.

often as gray whales in fall. Habitat selection of shallower water habitats $(\leq 35 \mathrm{~m}$ and $36-50 \mathrm{~m})$ was similar in the two species (Table 3).

\section{Comparison of Habitat Selection in 1982-91 and 2009-15}

Primary habitat preference results remained largely the same in the reanalyzed 1982-91 data for both species and in both seasons (Table 4), as reported in Moore et al. (2000).

Bowhead whales were not observed in summer 1982-91. In the results from reanalyzed data for summer 2009-15, bowheads in the northeastern Chukchi Sea showed the same strong preference for shelf/trough (51-200 m North) as reported above $\left(\mathrm{w}_{i}=2.250\right.$; Table 5$)$. In fall, bowhead whales were not uniformly distributed with respect to depth in either $1982-91$ or $2009-15$, and they selected similar habitats during both time periods. Bowhead whales selected shelf/trough habitat in the northeastern Chukchi Sea (51-200 m North) most often $\left(1982-91, \mathrm{w}_{i}=1.467\right.$; $\left.2009-15, \mathrm{w}_{i}=2.807\right)$ and were least likely to select coastal/ shoal habitat $\left(1982-91, \mathrm{w}_{i}=0.494 ; 2009-15, \mathrm{w}_{i}=0.152\right)$ (Table 5).

Gray whales were not uniformly distributed with respect to depth in summer or fall in either 1982-91 or 2009-15. In the northeastern Chukchi Sea, summer habitat preference in the reanalyzed $1982-91$ and $2009-15$ datasets was for coastal/shoal habitat $\left(\leq 35 \mathrm{~m}\right.$ depth; $1982-91, \mathrm{w}_{i}=$ $1.911 ; 2009-15, \mathrm{w}_{i}=1.368$ ). In the southern Chukchi Sea, no gray whales were sighted in shelf/trough habitat in summer 1982-91, whereas in summer 2009-15, overall habitat preference was decidedly for shelf/trough $(51-200 \mathrm{~m}$ South; $\left.\mathrm{w}_{i}=5.529\right)($ Table 5). In fall, gray whales overwhelmingly preferred shelf/trough (51-200 m South) in the southern Chukchi Sea during both $1982-91\left(\mathrm{w}_{i}=17.000\right)$ and 2009-15 $\left(\mathrm{w}_{i}=8.000\right)$ (Table 5), while in the northeastern Chukchi Sea, they were more likely to select coastal/ shoal habitat $\left(\leq 35 \mathrm{~m} ; \mathrm{w}_{i}=1.040\right)$ in $1982-91$ and shelf/ trough habitat (51-200 $\mathrm{m}$ North; $\left.\mathrm{w}_{i}=1.416\right)$ in 2009-15.

Sea ice habitat preference for the relatively few bowhead whales observed in summer 2009-15 was for moderately heavy ice cover $\left(41 \%-70 \%\right.$ ice cover; $\left.\mathrm{w}_{i}=1.863\right)$ and open water/light ice cover $\left(\leq 10 \%\right.$ ice cover; $\left.\mathrm{w}_{i}=1.067\right)$; bowhead whales were not seen in summer in 1982-91 (Table 6). Sea ice habitat selection of bowhead whales differed considerably in fall 1982-91 compared to fall 2009-15 (Table 6). In fall 1982-91, the bowheads preferred heavy ice cover $\left(>70 \%\right.$ ice cover; $\left.\mathrm{w}_{i}=2.800\right)$, with lowest preference for open water/light ice $\left(\leq 10 \%\right.$ ice cover; $\left.\mathrm{w}_{i}=0.234\right)$. Conversely, in fall 2009-15, bowhead whale habitat preference was entirely for open water/light ice cover $\left(\mathrm{w}_{i}=1.022\right)$. Gray whale ice cover habitat preference was for open water/ light ice cover $(\leq 10 \%$ ice cover) in both summer and fall in 1982-91 and 2009-15 (Table 6).

\section{DISCUSSION}

Data collected on large whales and other marine mammals in the eastern Chukchi Sea as part of the ASAMM project (and its precursors) span more than 30 years. Changes to the Arctic climate over the past several decades, including the loss of seasonal sea ice, increased ocean and air temperatures, and greater oceanic freshwater content, are well documented (e.g., Johannessen and Miles, 2011; Woodgate et al., 2012; Cohen et al., 2014). The magnitude of change, particularly since 2000 , has led to the concept 
TABLE 2. On-effort bowhead whales and gray whales by depth zone in the eastern Chukchi Sea, summer and fall, 2009-15. Tr + TrC $\mathrm{km}=$ transect plus circling-on-transect kilometers; observed $=\#$ of whales observed; expected $=$ \# of whales expected from effort per depth zone; $\chi^{2}$ indicates whether whales were distributed in proportion to survey effort.

\begin{tabular}{|c|c|c|c|c|c|c|c|c|c|c|}
\hline \multirow[b]{3}{*}{ Depth zone (m) } & \multirow{3}{*}{$\begin{array}{c}\text { Effort } \\
(\operatorname{Tr}+\operatorname{TrC~km)})\end{array}$} & \multicolumn{4}{|c|}{ Summer } & \multirow{3}{*}{$\begin{array}{c}\text { Effort } \\
(\operatorname{Tr}+\operatorname{TrC} \mathrm{km})\end{array}$} & \multicolumn{4}{|c|}{ Fall } \\
\hline & & \multicolumn{2}{|c|}{ Observed } & \multicolumn{2}{|c|}{ Expected } & & \multicolumn{2}{|c|}{ Observed } & \multicolumn{2}{|c|}{ Expected } \\
\hline & & Bowhead & Gray & Bowhead & Gray & & Bowhead & Gray & Bowhead & Gray \\
\hline Continental Shelf $(36-50 \mathrm{~m})$ & 40061 & 20 & 446 & 21.60 & 655.94 & 42178 & 215 & 181 & 252.94 & 214.29 \\
\hline Shelf/Trough North (51-200 m North) & 1) 16130 & 17 & 236 & 8.70 & 264.10 & 14680 & 267 & 71 & 88.03 & 74.58 \\
\hline Shelf/Trough South (51-200 m South) & 1684 & 0 & 150 & 0.91 & 27.57 & 1978 & 1 & 152 & 11.86 & 10.05 \\
\hline Total & 90879 & 49 & 1488 & 49.00 & 1488.00 & 86211 & 517 & 438 & 517.00 & 438.00 \\
\hline
\end{tabular}

TABLE 3. Depth zone selection ratios $\left(\mathrm{w}_{i}\right)$ for bowhead whales and gray whales in the eastern Chukchi Sea, summer and fall, $2009-15$. $\pi_{i}$ represents the proportion of survey effort per depth zone, $\mathrm{o}_{i}$ is the proportion of whales observed in each depth zone, and $\mathrm{w}_{i}=\mathrm{o}_{i} / \pi_{i}$.

\begin{tabular}{|c|c|c|c|c|c|}
\hline \multirow[b]{2}{*}{ Depth zone (m) } & \multirow[b]{2}{*}{$\pi_{\mathrm{i}}$} & \multicolumn{2}{|c|}{ Bowhead whales } & \multicolumn{2}{|c|}{ Gray whales } \\
\hline & & $\mathrm{o}_{i}$ & $\mathrm{~W}_{i}$ & $\mathrm{o}_{i}$ & $\overline{\mathrm{W}_{i}}$ \\
\hline \multicolumn{6}{|l|}{ Summer: } \\
\hline Continental Shelf $(36-50 \mathrm{~m})$ & 0.441 & 0.408 & 0.925 & 0.300 & 0.680 \\
\hline Shelf/Trough North (51-200 m North) & 0.177 & 0.347 & 1.960 & 0.159 & 0.898 \\
\hline Shelf/Trough South (51-200 m South) & 0.019 & 0.000 & 0.000 & 0.101 & 5.316 \\
\hline Total & 1.000 & 1.000 & 3.560 & 1.000 & 8.109 \\
\hline Continental Shelf $(36-50 \mathrm{~m})$ & 0.489 & 0.416 & 0.851 & 0.413 & 0.845 \\
\hline Shelf/Trough North (51-200 m North) & 0.170 & 0.516 & 3.035 & 0.162 & 0.953 \\
\hline Shelf/Trough South (51-200 m South) & 0.023 & 0.002 & 0.087 & 0.347 & 15.087 \\
\hline Total & 1.000 & 1.000 & 4.181 & 1.000 & 17.130 \\
\hline
\end{tabular}

of a "new normal" Arctic ecosystem (Jeffries et al., 2013; Wood et al., 2015). Our intent with this paper was to summarize bowhead and gray whale data obtained from the eastern Chukchi Sea since the onset of the "new normal," and replicate the analyses originally conducted by Moore et al. (2000) of large whale habitat preference to investigate changes over a greater than 30 -year time span.

\section{Caveats Concerning Data Collection, 1982-15}

Aerial survey protocols used to collect bowhead and gray whale data in 2009-15 closely replicated those used during 1982-91, and consistent methods were used in the habitat selection analyses conducted here for both time periods. However, differences in technologies, survey platforms, effort, and environmental conditions between the two time periods that could affect interpretation of results are worth mentioning.

- First, while methods and protocols for cetacean data collection and analysis remained similar, accuracy and precision of field data improved dramatically because of technological advances over three decades. For example, portable GPS systems using satellite data interfaced directly into laptop computers on the survey aircraft allowed for more accurate determination of tracklines and sighting locations in 2009-15 than was possible with the dead reckoning-based Global Navigation
System used from 1982 to 1991. Furthermore, with powerful laptop computers and specialized software, far greater quantities of field data (e.g., sighting, environmental, position) could be collected in $2009-15$. These innovations provided more flexibility in data collection, including the ability to record individual circling events precisely and accurately and subsequently to distinguish circling effort and sightings from those on transect, which was not possible during 1982-91.

- Second, the International Bathymetric Chart of the Arctic Ocean dataset used for the current depth zone analysis allowed for more precise and accurate delineation of depth zones than the coarser bathymetric blocks used by Moore et al. (2000). One result was the placement of Hanna Shoal in the continental shelf (36-50 m depth) zone in the current analysis of data from both time periods, rather than in the coastal/shoal ( $\leq 35 \mathrm{~m}$ depth) zone.

- Third, there were differences in the temporal and spatial extents of data collected in 1982-91 and 2009-15. The current study area represents part of the study area analyzed by Moore et al. (2000) and was selected as the focus of this paper to investigate potentially overlapping habitat use by bowhead and gray whales. Additionally, because of BOEM's commitment to fund broad-scale marine mammal aerial surveys throughout the entire open water season in the eastern Chukchi Sea, total 
TABLE 4. Summary of results for seasonal depth zone and sea ice cover habitat preferences for bowhead whales and gray whales from Moore et al. (2000), the current reanalysis for 1982-91, and the current analysis for 2009-15.

\begin{tabular}{|c|c|c|c|}
\hline & $1982-91^{1}$ & 1982-91 Reanalysis ${ }^{2}$ & $2009-15^{2}$ \\
\hline Depth habitat: & & See Table 5 . & See Table 5. \\
\hline \multicolumn{4}{|l|}{ Bowhead whales } \\
\hline Summer & No sightings. & No sightings. & $\begin{array}{l}\text { Strongest association with shelf/trough in } \\
\text { northeastern Chukchi Sea; least selection } \\
\text { for coastal/shoal; no selection for shelf/ } \\
\text { trough in southern Chukchi Sea. }\end{array}$ \\
\hline Fall & $\begin{array}{l}\text { Distributed uniformly across all depths } \\
\text { with some preference for shelf/trough; least } \\
\text { selection for shelf (see Table } 9 \text { ). }\end{array}$ & $\begin{array}{l}\text { Strongest association with shelf/trough in } \\
\text { northeastern Chukchi Sea; least selection } \\
\text { for coastal/shoal. }\end{array}$ & $\begin{array}{l}\text { Strongest association with shelf/trough in } \\
\text { northeastern Chukchi Sea; least selection } \\
\text { for coastal/shoal. }\end{array}$ \\
\hline \multicolumn{4}{|c|}{ 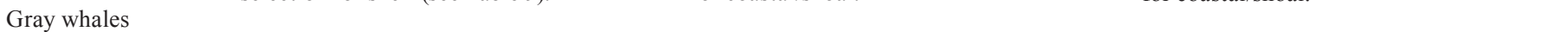 } \\
\hline Summer & $\begin{array}{l}\text { Strong association with coastal/shoal } \\
\text { habitat; least selection for shelf } \\
\text { (see Table 7). }\end{array}$ & $\begin{array}{l}\text { Strongest association with coastal/shoal } \\
\text { habitat; least selection for shelf/trough in } \\
\text { northeastern Chukchi Sea; no selection for } \\
\text { shelf/trough in southern Chukchi Sea. }\end{array}$ & $\begin{array}{l}\text { Strongest association with shelf/trough in } \\
\text { southern Chukchi Sea; least selection for } \\
\text { shelf/trough in northeastern Chukchi Sea } \\
\text { and shelf. }\end{array}$ \\
\hline Fall & $\begin{array}{l}\text { Very strong association with shelf/trough; } \\
\text { least selection for shelf (see Table 13). }\end{array}$ & $\begin{array}{l}\text { Very strong association with shelf/trough } \\
\text { in southern Chukchi Sea; least selection for } \\
\text { shelf/trough in northeastern Chukchi Sea. }\end{array}$ & $\begin{array}{l}\text { Very strong association with shelf/trough } \\
\text { in southern Chukchi Sea; least selection for } \\
\text { coastal/shoal. }\end{array}$ \\
\hline Ice cover habitat: & & See Table 6. & See Table 6. \\
\hline \multicolumn{4}{|l|}{ Bowhead whales } \\
\hline Summer & No sightings. & No sightings. & $\begin{array}{l}\text { Strongest association with moderately } \\
\text { heavy }(41 \%-70 \%) \text { ice cover. }\end{array}$ \\
\hline Fall & $\begin{array}{l}\text { Strongest association with heavy ice habitat } \\
(>70 \%) \text { (see Table } 11) \text {. }\end{array}$ & $\begin{array}{l}\text { Strongest association with heavy ice habitat } \\
(>70 \%) \text {. }\end{array}$ & $\begin{array}{l}\text { Only sighted in open water/light ice habitat } \\
(\leq 10 \%) \text {. }\end{array}$ \\
\hline \multicolumn{4}{|l|}{ Gray whales } \\
\hline Summer & $\begin{array}{l}\text { Strongly associated with open water/light } \\
\text { ice habitat }(\leq 10 \%) \text {. }\end{array}$ & $\begin{array}{l}\text { Strongly associated with open water/light } \\
\text { ice habitat }(\leq 10 \%) \text {. }\end{array}$ & $\begin{array}{l}\text { Strongly associated with open water/light } \\
\text { ice habitat }(\leq 10 \%) \text {. }\end{array}$ \\
\hline Fall & $\begin{array}{l}\text { Strongly associated with open water/light } \\
\text { ice habitat }(\leq 10 \%) \text {. }\end{array}$ & $\begin{array}{l}\text { Strongly associated with open water/light } \\
\text { ice habitat }(\leq 10 \%) \text {. }\end{array}$ & $\begin{array}{l}\text { Only sighted in open water/light ice cover } \\
(\leq 10 \%)\end{array}$ \\
\hline
\end{tabular}

${ }^{1}$ Data from Moore et al. (2000).

${ }^{2}$ Data from this study.

survey effort in 2009-15 was nine times as great in summer and 1.5 times as great in fall as survey effort in 1982-91 (Tables 5 and 6).

- Fourth, although there was significant interannual variability, sea ice remained in the northeastern Chukchi Sea in most years from 1982 to 1991 and could be used as a variable for habitat selection (Moore, 2000; Moore et al., 2000). Arctic sea ice extent has declined sharply since 1953 (e.g., Stroeve et al., 2007; Kwok and Rothrock, 2009; Kwok and Untersteiner, 2011), with record minima in summer sea ice extent recorded in 2007 and again in 2012 (Wood et al., 2015). Sea ice was largely absent from the eastern Chukchi Sea study area after early to midAugust each year from 2009 to 2015 (Clarke et al., 2011, 2012, 2013b, 2014, 2015), so the only truly meaningful habitat variable included in this analysis, particularly for fall, was depth. Sea ice, or the lack thereof, also has the potential to affect aerial survey effort because the absence of sea ice generally leads to higher sea states in windy conditions, and higher sea states reduce detection probabilities. ASAMM survey protocol dictated that surveys not be conducted in sea states greater than Beaufort 5 , and transects that could not be surveyed initially because of high sea states were surveyed as soon as lower sea states allowed. These circumstances likely occurred more often in 2009-15 than in 1982-91, when sea ice often remained in the study area.

- Last but certainly not least, perhaps the biggest difference between data collected in the two time periods was the survey platform. Although a few of the surveys conducted from 1982 to 1991 were flown in a de Havilland Twin Otter (Moore and Clarke, 1991), most of the data collected by Moore et al. (2000) were obtained using a Grumman Goose, an aircraft lacking bubble windows that maintained a survey speed about $80 \mathrm{~km} /$ hr faster than the survey speed used in 2009-15. The faster speed means that transects were surveyed more quickly, and the lack of bubble windows means that detections of sightings directly under the aircraft were not possible from 1982 to 1991 . These factors likely contributed to lower sighting probabilities in 1982-91 than in 2009-15. Indeed, Ferguson and Clarke (2013) determined that detectability of bowhead and gray whales differed slightly even between Twin Otters and Aero Commanders, both aircraft that were outfitted with bubble windows and conducted surveys at similar survey 
TABLE 5. Comparison of seasonal depth zone selection ratios $\left(\mathrm{w}_{i}\right)$ for bowhead whales and gray whales, $1982-91$ and $2009-15$. $\pi_{i}$ represents the proportion of survey effort per depth zone, $\mathrm{o}_{i}$ is the proportion of whales observed in each depth zone, and $\mathrm{w}_{i}=\mathrm{o}_{i} / \pi_{i}$. $\operatorname{Tr} \mathrm{km}=$ transect kilometers; \# observed = number of whales observed. Total Tr km numbers differ slightly from those in Table 6 due to different methods for summarizing effort.

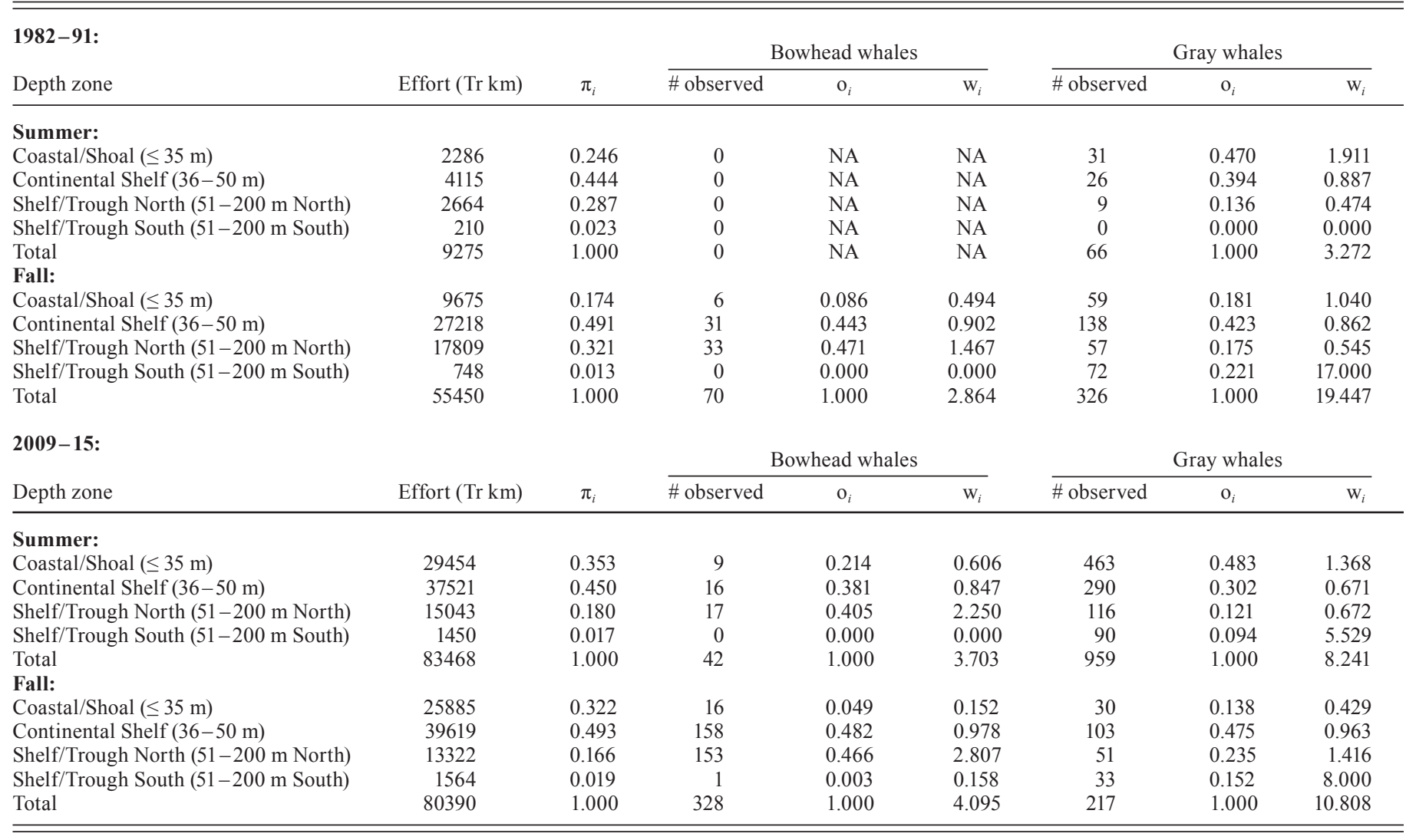

speeds. As noted in Ferguson and Clarke (2013), a similar analysis using data collected using the Grumman Goose would be difficult to undertake because crucial data (specifically, differentiation of sightings from primary vs. secondary observers) were not collected at that time.

Collectively, the differences in data collection and sampling protocols and platforms between 1982-91 and 2009-15 preclude direct comparison of sighting rates and underscore the importance of using habitat selection ratios from within each time period to allow for comparisons across time. Nevertheless, intriguing questions remain regarding the differences in the number of bowhead and gray whales observed in each time period.

\section{Lingering Questions about Whale Numbers}

More bowhead whales were seen in summer and fall 2009-15 (42 and 328, respectively) than in summer and fall 1982-91 (0 and 70, respectively). The proliferation of bowhead whale sightings in 2009-15 may be due to greater total survey effort (Table 5), better detection probabilities from a survey aircraft traveling at a slower speed and outfitted with bubble windows, a larger Bering-ChukchiBeaufort bowhead whale population $(6928[\mathrm{CV}=0.120]$ in 1988; 16892 [CV = 0.244] in 2011; Zeh and Punt, 2004; Givens et al., 2013), or a combination of these and other factors.

The number of gray whales observed in summer 2009-15 ( $\mathrm{n}=959)$ far exceeded the number observed in summer 1982-91 $(\mathrm{n}=66)$ (Table 5), which might be expected considering the greater effort in the more recent time period. However, the number of gray whales observed in fall 2009-15 $(\mathrm{n}=217)$ was less than the number observed in fall 1982-91 $(\mathrm{n}=326)$ (Table 5), despite greater total survey effort and survey platform effects that likely increased detection probability. Annual variability in gray whale density in the eastern Chukchi Sea is likely related to several factors that are largely unknown in any given year, including the proportion of the Eastern North Pacific (ENP) gray whale population that migrates into the eastern Chukchi Sea, the timing of the onset of southbound migration, foraging opportunities, age, sex, and overall population size. ASAMM data provide limited information about the timing of the southbound migration and some information on benthic foraging opportunities from the conspicuous mud plumes associated with this type of feeding. However, without the ability to identify and track the movements of individual gray whales that migrate to the eastern Chukchi Sea study area, we cannot estimate what proportion of the population is found in the study area each 
TABLE 6. Comparison of seasonal sea ice cover selection ratios $\left(\mathrm{w}_{i}\right)$ for bowhead whales and gray whales, 1982-91 and $2009-15$. $\pi_{i}$ represents the proportion of survey effort per ice cover category, $\mathrm{o}_{i}$ is the proportion of whales observed in each ice cover category, and $\mathrm{w}_{i}=\mathrm{o}_{i} / \pi_{i}$. Tr km = transect kilometers; \# observed = number of whales observed. Total Tr km numbers differ slightly from those in Table 5 because a different method for summarizing effort was used.

\begin{tabular}{|c|c|c|c|c|c|c|c|c|}
\hline \multirow{2}{*}{$\begin{array}{l}\text { 1982 -91: } \\
\text { Ice cover category }(\%)\end{array}$} & \multirow[b]{2}{*}{ Effort (Tr km) } & \multirow[b]{2}{*}{$\pi_{i}$} & \multicolumn{3}{|c|}{ Bowhead whales } & \multicolumn{3}{|c|}{ Gray whales } \\
\hline & & & \# observed & $\mathrm{o}_{i}$ & $\overline{\mathrm{w}_{i}}$ & \# observed & $\mathrm{o}_{i}$ & $\overline{\mathrm{w}_{i}}$ \\
\hline \multicolumn{9}{|l|}{ Summer: } \\
\hline $0-10$ & 4946 & 0.534 & 0 & NA & NA & 60 & 0.909 & 1.702 \\
\hline $11-40$ & 657 & 0.071 & 0 & NA & NA & 6 & 0.091 & 1.282 \\
\hline $41-70$ & 514 & 0.055 & 0 & NA & NA & 0 & 0.000 & 0.000 \\
\hline $71-100$ & 3150 & 0.340 & 0 & NA & NA & 0 & 0.000 & 0.000 \\
\hline Total & 9267 & 1.000 & 0 & NA & NA & 66 & 1.000 & 2.984 \\
\hline \multicolumn{9}{|l|}{ Fall: } \\
\hline $0-10$ & 36230 & 0.670 & 11 & 0.157 & 0.234 & 314 & 0.963 & 1.437 \\
\hline $11-40$ & 1898 & 0.035 & 5 & 0.071 & 2.029 & 1 & 0.003 & 0.086 \\
\hline $41-70$ & 2467 & 0.046 & 5 & 0.071 & 1.543 & 2 & 0.006 & 0.130 \\
\hline $71-100$ & 13520 & 0.250 & 49 & 0.700 & 2.800 & 9 & 0.028 & 0.112 \\
\hline Total & 54115 & 1.000 & 70 & 1.000 & 6.606 & 326 & 1.000 & 1.765 \\
\hline \multicolumn{3}{|l|}{ 2009-15: } & \multicolumn{3}{|c|}{ Bowhead whales } & \multicolumn{3}{|c|}{ Gray whales } \\
\hline Ice cover category $(\%)$ & Effort (Tr km) & $\pi_{i}$ & \# observed & $\mathrm{o}_{i}$ & $\mathrm{w}_{i}$ & \# observed & $\mathrm{o}_{i}$ & $\mathrm{w}_{i}$ \\
\hline \multicolumn{9}{|l|}{ Summer: } \\
\hline $0-10$ & 67460 & 0.803 & 36 & 0.857 & 1.067 & 891 & 0.929 & 1.157 \\
\hline $11-40$ & 5630 & 0.067 & 2 & 0.048 & 0.716 & 49 & 0.051 & 0.761 \\
\hline $41-70$ & 4303 & 0.051 & 4 & 0.095 & 1.863 & 15 & 0.016 & 0.314 \\
\hline $71-100$ & 6600 & 0.079 & 0 & 0.000 & 0.000 & 4 & 0.004 & 0.051 \\
\hline Total & 83993 & 1.000 & 42 & 1.000 & 3.646 & 959 & 1.000 & 2.283 \\
\hline \multicolumn{9}{|l|}{ Fall: } \\
\hline $0-10$ & 79136 & 0.978 & 328 & 1.000 & 1.022 & 217 & 1.000 & 1.022 \\
\hline $11-40$ & 368 & 0.005 & 0 & 0.000 & 0.000 & 0 & 0.000 & 0.000 \\
\hline $41-70$ & 572 & 0.007 & 0 & 0.000 & 0.000 & 0 & 0.000 & 0.000 \\
\hline $71-100$ & 823 & 0.010 & 0 & 0.000 & 0.000 & 0 & 0.000 & 0.000 \\
\hline Total & 80899 & 1.000 & 328 & 1.000 & 1.022 & 217 & 1.000 & 1.022 \\
\hline
\end{tabular}

year or the residence times of individual whales. Without genetic sampling, sex determination is not possible, except that we assume a large whale closely associated with a calf is female. Similarly, without a way to identify individual whales, we can categorize gray whales into only two age categories: calf or non-calf. Population estimates for ENP gray whales in the last 30 years have varied from a high of $26916(\mathrm{CV}=0.058)$ in $1987-88$ to a low of $15762(\mathrm{CV}$ $=0.080$ ) in 1992-93 (Laake et al., 2012). The most current ENP estimate (20 990; $\mathrm{CV}=0.050)$ is from the census conducted in 2010-11 (Durban et al., in press). Given the uncertainty in historical and recent abundance estimates, and the lack of abundance estimates after 2011, there is insufficient information to determine how ENP population sizes compare between the earlier and later survey periods.

\section{Distribution and Behavior}

Bowhead whales remain relatively uncommon in the eastern Chukchi Sea in summer. They were never observed in the northeastern Chukchi Sea in summer 1982-91 (Moore et al., 2000), and although bowhead whales were seen in summer months each year from 2009 to 2015, they were few in number. Moore (1992) also noted the scarcity of bowhead whales in summer from sources other than the MMS-sponsored marine mammal aerial surveys: the summary of records of incidental bowhead whale sightings from vessel, shore, and aerial platforms (other than the 1982-91 study reanalyzed here) in the northeastern Chukchi Sea from 1975 to 1991 identified only three sightings west of Point Barrow in June or July. Summer observations of bowhead whales in the northeastern Chukchi Sea near Point Franklin were recorded in July 2003 (Moore et al., 2010), and a few bowhead whales were seen during oil industry-sponsored aerial surveys near the northwestern Alaskan coast in July 2006 (four whales) and 2008 (four whales) (Thomas et al., 2010). Few bowhead whales were seen during vessel-based visual surveys in the northeastern Chukchi Sea in 2008-10 (Aerts et al., 2013), and relatively few bowhead whale calls were recorded in summer during year-round passive acoustic studies conducted from 2007 to 2011 (Hannay et al., 2013). The relative scarcity of bowhead whales observed in the northeastern Chukchi Sea in summer is likely due to better foraging opportunities elsewhere, specifically in the Beaufort Sea. Feeding areas in the Canadian Beaufort Sea are well documented (Harwood et al., 2010; Citta et al., 2015), but bowhead whales, many observed feeding, were also seen regularly in the western Beaufort Sea in summer 2012-14 (Clarke et al., 2015). The scarcity of bowhead whale sightings in the Chukchi Sea in summer may also be due to boundaries of the 2009-15 ASAMM study area. The two satellite-tagged 
bowhead whales that made round trips between Amundsen Gulf and an area northwest of Barrow in summer 2009 were well north of the ASAMM study area during the time they spent in the Chukchi Sea (Quakenbush et al., 2010). Bowhead whales observed in the northeastern Chukchi Sea during summer may be late migrants to, or early returnees from, summer feeding areas in the Beaufort Sea. Conversely, some of the bowhead whales observed in summer in the northeastern Chukchi Sea may not undergo a complete spring migration to the eastern Beaufort Sea, similar to gray whales that do not undergo a complete annual migration between the Arctic and Mexico (Calambokidis et al., 2002; Moore et al., 2007; Rugh et al., 2008).

Bowhead whale distribution and swim direction $\left(266^{\circ}\right.$ True bearing) in fall 2009-15, when sighting rates were 12 times as great as in summer 2009-15, implied a broad west-southwest migration direction across the northeastern Chukchi Sea (as suggested in Moore and Clarke, 1990), particularly in October. Bowhead whales satellite-tagged in 2006-10 (Quakenbush et al., 2010, 2013) also showed a west-southwest fall migration, in addition to a more northwesterly route for whales presumably heading towards Wrangel Island and the northern Chukotka coast. Fall migration can also be inferred from acoustic data collected via hydrophones deployed at several locations offshore from Point Lay, Alaska, to Point Barrow, which detected bowhead whale calls several hundred kilometers west of Barrow and Wainwright in September and October (Hannay et al., 2013) and as late as December (Delarue et al., 2009). Core-use areas designated on the basis of bowhead whale satellite-tag data collected from 2006 to 2012 were not defined for any region in the eastern Chukchi Sea, indicating that bowhead whales are mainly migrating in that area in fall (Citta et al., 2015). Similarly, Kuletz et al. (2015) identified bowhead whale hotspots in the western Beaufort Sea but not in the eastern Chukchi Sea on the basis of ASAMM summer and fall sighting data from 2007 to 2012.

Gray whales remained ubiquitous in the eastern Chukchi Sea throughout summer and fall. Sighting rates in 2009-15 decreased from July through October in most of the study area, reflecting the migration timing of gray whales in northern Alaskan waters (Rugh et al., 2001). Sighting rates in the Hope Valley remained almost unchanged between summer and fall 2009-15, indicating that gray whales remained resident longer in that area or were replaced by whales that had migrated from other areas. This temporal pattern was similar to that observed from 1982 to 1987 (Clarke et al., 1989) and during surveys sponsored by the oil industry in 2006-08 (Thomas et al., 2010). Feeding remained the predominant behavior recorded for gray whales in 2009-15, despite the fact that it was likely underreported because non-benthic feeding is difficult to detect from aerial surveys. The relative lack of gray whales on Hanna Shoal in 2009-15 may reflect changes in benthic prey assemblages due to loss of seasonal ice that are not yet well understood (Grebmeier et al., 2015). Gray whales were observed on Hanna Shoal in fall in the late 1980s during a small proportion of survey flights in that area (Moore and Clarke, 1992).

The highest gray whale sighting rates in summer and fall 2009-15 were in the Hope Valley in the southern Chukchi Sea. Gray whales were seen there in fall 1982-91, but not in summer of those years (Moore et al., 2000). Incidental records of historical gray whale occurrence, summarized in Clarke et al. (1989), indicate that the southern Chukchi Sea likely has been important gray whale habitat from late summer through fall for several decades, although most historical records were from west of the International Dateline near the Chukotka Peninsula. The complete lack of gray whale observations in the southern Chukchi Sea in summer 1982-91 may be due to the scarcity of survey effort in that area (Table 5; 2.3\% of total effort in shelf/trough South). In summer 2009-15, when gray whale sighting rates were significantly higher than elsewhere in the eastern Chukchi Sea, the percentage of total survey effort in that same depth zone was lower (Table 5; 1.7\%) than in 1982-91. However, total effort in summer $2009-15(1450 \mathrm{~km})$ was nearly seven times greater than effort in $1982-91(210 \mathrm{~km})$.

\section{Habitat Partitioning}

Habitat partitioning described by depth preference between bowhead and gray whales was noted in Moore et al. (2000) for data collected in 1982-91 and remained evident in 2009-15, albeit in different ways. In summer 2009-15, both species were most strongly associated with shelf/trough habitats but in different areas. Bowhead whales preferred shelf/trough (including Barrow Canyon) in the northeastern Chukchi Sea and gray whales preferred shelf/trough (including Hope Valley) in the southern Chukchi Sea (Table 3). Both species showed some selection of other habitats, indicating habitat overlap, especially in summer. Habitat partitioning between the two species continued in fall 2009-15, with highest selection for the same respective shelf/trough areas as in summer. In fall, bowhead whales were three times as likely as gray whales to be found in shelf/trough habitat in the northeastern Chukchi Sea (Table 5). Bowhead whales showed no preference for shelf/trough in the southern Chukchi Sea, although that was likely due to the timing of the aerial surveys. Satellitetagged bowhead whales traversed the Hope Valley area, but not until November and December (Quakenbush et al., 2010) after ASAMM aerial surveys had ended. Coastal/ shoal habitat was least preferred by both species in fall 2009-15. Fall sighting distributions (Fig. 3B and 4B) also indicate some shared use of shelf habitat.

Analysis of habitat selection preferences within each time period, 1982-91 and 2009-15, allowed for comparisons over time. Bowhead whales consistently preferred shelf/trough habitat in the northeastern Chukchi Sea in fall over a 34-year span (Table 5) despite the changing physical and biological environment. Gray whale primary depth habitat association in fall also remained the same over the 34 years, with selection overwhelmingly for shelf/trough in the 
southern Chukchi Sea. In the northeastern Chukchi Sea in fall, a shift occurred in gray whale preference from coastal/ shoal in 1982-91 to shelf/trough in 2009-15. Brower et al. (in press), using sighting data from ASAMM and benthic sampling data collected during the BOEM-sponsored COMIDA CAB project from 2009 to 2012 (Schonberg et al., 2014), showed that infaunal amphipod abundance and biomass closely mirrored areas of highest gray whale abundance, with greatest abundance of both over shelf/trough depths south and west of Barrow Canyon. The gray whale foraging area described by Brower et al. (in press) is located along a hydrographic front formed where Alaska Coastal Water meets Bering Sea/Anadyr Water, an area of high productivity that fluctuates depending on factors including seasonal sea ice extent, sea water temperature, and water mass structure (Grebmeier et al., 2006; Weingartner et al., 2013). The lack of sea ice in this area in fall 2009-15 may have improved primary production, and subsequently benthic biomass, in deeper offshore waters compared to coastal waters.

The most pronounced difference in depth preference between 1982-91 and 2009-15 was for gray whales in summer, when habitat preference shifted from coastal/shoal in 1982-91 to shelf/trough (Hope Valley) in the southern Chukchi Sea in 2009-15. The limited survey effort in the southern Chukchi Sea in 1982-91, discussed above, may have played a role, but it is also possible that the complete lack of gray whale observations in Hope Valley in summer 1982-91 indicates that the area was not the benthic hotspot that it is now (Kuletz et al., 2015). Decadal distributions of sediment community oxygen consumption, an indicator of carbon supply to the benthos, and infaunal benthic biomass in the Pacific Arctic region illustrate the changes that have occurred in the Chukchi Sea since the 1970s (Grebmeier, 2012). The benthic infaunal community in the Hope Valley, which has increased in biomass over several decades (see Grebmeier, 2012: Fig. 4), is currently dominated by bivalves, polychaetes, and amphipods, the latter of which are preferred prey of gray whales (Grebmeier et al., 2015).

\section{Effects of Sea Ice Loss on Aerial Survey Data}

Sea ice conditions in summer and fall in the Chukchi Sea study area have changed markedly in the last three decades. Moore (2000) identified three years of heavy ice cover $(1983,1988,1991)$ and four years of moderate ice cover $(1982,1984,1985,1987)$ within the 1982-91 time period, which contrasts with summer and fall ice conditions during 2009-15. The percentage of survey effort per ice category $\left(\pi_{\mathrm{i}}\right)$ per season in $2009-15$ reflects the reduction over time of sea ice in the study area (Table 6), with $80 \%$ of total effort in summer and $98 \%$ of total effort in fall occurring in ice-free or light ice $(\leq 10 \%$ ice cover) conditions. The lack of sea ice lessens the significance of the sea ice habitat preference analysis for 2009-15, particularly in fall, when all bowhead and gray whales were observed in light ice. In summer 2009-15, bowhead whales showed greater preference for moderately heavy ice conditions, while gray whales preferred light ice conditions. Bowhead whale distribution extended farther north (Fig. 3A), where receding summer sea ice lingers later in the year, than gray whale distribution (Fig. 4A). It is unknown whether gray whales selected southerly habitats because of the heavier ice concentrations to the north, or if other factors, such as better foraging opportunities, limited their latitudinal distribution.

Sea ice cover likely has minimal impact on bowhead whale movements because bowhead whales are ice-adapted and have been documented in areas of heavy sea ice cover (George et al., 1989; Quakenbush et al., 2010; Citta et al., 2012). However, sea ice cover does affect primary and secondary productivity (Arrigo et al., 2008; Arrigo and van Dijken, 2015), and it is likely that the significant reduction in summer sea ice cover evident in the Chukchi Sea each year since 2000 (Frey et al., 2015) has affected primary and secondary productivity and influenced prey advection (Moore and Laidre, 2006; Grebmeier et al., 2015). These changes may result in opportunities for bowhead whale feeding during the fall migration that were not available 30 years ago. The northeastern Chukchi Sea has never been identified as a prime feeding area for bowhead whales, and relatively few whales were recorded as feeding from 2009 to 2015. However, bowhead whales are known to feed immediately east of the study area on dense aggregations of krill that are advected from the Bering Sea into the Chukchi Sea via the Alaskan Coastal Current (Ashjian et al., 2010) and Bering Sea/Anadyr Water (Berline et al., 2008). The transport of krill varies with changes in atmospheric conditions, and bowhead whales in the northeastern Chukchi Sea may forage opportunistically on krill during this transport when oceanographic conditions produce optimal foraging opportunities.

As mentioned previously, the lack of sea ice has the potential to negatively or positively affect detection probabilities during aerial surveys because sea states increase more readily in windy conditions when sea ice is not present, and it is generally more difficult to detect whales in high sea states. Alternatively, the presence of sea ice could interfere with the process of detecting whales because sea ice introduces false targets into a marine mammal observer's viewing field. Limiting survey effort to areas in which sea state was Beaufort Sea State 5 or less mitigates the first issue for bowhead and gray whales. In MMS-sponsored aerial surveys conducted on a Twin Otter (primarily in the Beaufort Sea) from 1989 to 2008, there were sufficient sightings in more than $10 \%$ sea ice cover to evaluate sea ice effect on detection probabilities for bowhead whales and belugas; sea ice cover had no measureable effect on the detection probability for bowhead whales, but sea ice cover greater than $10 \%$ decreased the detection probability for belugas (Ferguson and Clarke, 2013). In ASAMM surveys conducted from 2009 to 2012, there were an insufficient number of bowhead and gray whale sightings made when sea ice covered more than $10 \%$ of the viewing area to evaluate its effects on detection probability. In any case, directly 
comparing sighting rates between historical surveys conducted on a Grumman Goose and recent surveys conducted on Twin Otters or Turbo Commanders is not advisable because of previously mentioned differences in survey platforms that affect detection probabilities.

\section{Management Implications}

The eastern Chukchi Sea encompasses active offshore oil and gas lease areas secured during the Chukchi Sea Outer Continental Shelf (OCS) Oil and Gas Lease Sale 193 held in February 2008. Exploration activities, including seismic, geohazard, and geotechnical surveys, occurred in 2009-15, and exploratory drilling was conducted in 2012 and 2015. The Department of the Interior recently completed a second supplemental environmental impact statement for Lease Sale 193, and the record of decision reaffirmed a 25-mile coastal buffer withdrawal extending from Point Barrow to Point Hope and a deferral corridor along the coastward edge of the Chukchi Sea Planning Area, and added a subsistence withdrawal in the Barrow Canyon area (U.S. DOI, 2015). The shelf/trough habitats preferred by bowhead and gray whales in the northeastern and southern Chukchi Sea in summer and fall are almost entirely outside of the current Lease Sale 193 deferral areas. Deferral areas also do not preclude support activities, including vessel shuttles and helicopter overflights, from occurring in habitat used by bowhead and gray whales in summer and fall. In addition to oil and gas activities, annual vessel activity includes container and other cargo vessels, community resupply, tugs, tankers, research, adventure or ecological tourism, and military operations, which are expected to increase substantially in the next decade (Azzara et al., 2015). Most of these activities occur within $50 \mathrm{~km}$ of shore in the eastern Chukchi Sea, overlapping with bowhead and gray whale habitat throughout summer and fall. As bowhead and gray whales encounter increasing levels of anthropogenic activity, changes in cetacean habitat preference, distribution, and relative density may be expected.

\section{CONCLUSIONS}

The eastern Chukchi Sea remains important habitat for bowhead and gray whales. From 2009 to 2015, gray whales were more abundant in summer and bowhead whales more abundant in fall in the northeastern Chukchi Sea; gray whales were most abundant in the Hope Valley area of the southern Chukchi Sea in both seasons. In areas where distributions overlapped, behavioral observations indicated that each species used the habitat for different purposes. Gray whales were feeding throughout summer and fall, whereas bowhead whales were migrating, primarily in fall. Despite the drastic changes in physical and biological environment, habitat preference based on depth zone in the eastern Chukchi Sea remained very similar between 1982-91 and 2009-15 for bowhead and gray whales in fall; however, gray whales no longer prefer coastal/shoal habitat in summer as they did in 1982-91. Bowhead and gray whales both demonstrated strongest preference for shelf/trough habitat in summer and fall, albeit in different regions of the eastern Chukchi Sea: bowhead whales in the northeastern Chukchi Sea and gray whales in the southern Chukchi Sea. Data collected via the ASAMM project, combined with information from other research efforts including physical, chemical, and biological sampling, satellite tagging, and passive acoustic monitoring, will continue to improve our understanding of the temporal and spatial nature of bowhead and gray whale distribution, density, and habitat association patterns in the eastern Chukchi Sea, including the impacts of climate change and anthropogenic activities.

\section{ACKNOWLEDGEMENTS}

Funding for and co-management of aerial surveys in the northeastern Chukchi Sea were provided by the Bureau of Ocean Energy Management (BOEM), Alaska OCS Region (formerly, the Minerals Management Service) under Interagency Agreement Nos. M08PG20023 and M11PG00033, where we particularly appreciate the support and guidance of Jeffrey Denton, Carol Fairfield, and Charles Monnett. The ASAMM project was co-managed by the Marine Mammal Laboratory, Alaska Fisheries Science Center, NOAA, where we appreciate the support and assistance of Robyn Angliss, Stefan Ball, John Bengtson, Amelia Brower, Cynthia Christman, Phillip Clapham, Mary Foote, Nancy Friday, David Rugh, Kim Shelden, Joanne Wejak, and Amy Willoughby. Mike Hay, of XeraGIS, provided invaluable and timely software support. Earlier versions of this paper were improved by comments from Thomas Evans, U.S. Fish and Wildlife Service; Geof Givens, Colorado State University; Lori Quakenbush, Alaska Department of Fish and Game; Brenda Rone, National Marine Fisheries Service; Robert Suydam, North Slope Borough Department of Wildlife Management; and one anonymous reviewer. This manuscript was greatly improved by comments provided by Sue Moore, Pacific Marine Environmental Laboratory, NOAA, and reviews by John Citta, Alaska Department of Fish and Game, Robert Suydam, and one anonymous reviewer. Numerous observers, pilots, mechanics, programmers, and other staff deserve our unmitigated appreciation for conducting surveys safely and effectively, collecting high-quality data, and carrying out numerous analyses. We also thank the North Slope Borough Department of Wildlife Management and National Weather Service personnel in Barrow for their continued assistance and the villages of Barrow and Kotzebue for their hospitality during the field seasons. The findings and conclusions in the paper are those of the authors and do not necessarily represent the views of the National Marine Fisheries Service. Reference to trade names does not imply endorsement by the National Marine Fisheries Service, NOAA. 


\section{REFERENCES}

Aerts, L.A.M., McFarland, A.E., Watts, B.H., Lomac-MacNair, K.S., Seiser, P.E., Wisdom, S.S., Kirk, A.V., and Schudel, C.A. 2013. Marine mammal distribution and abundance in an offshore sub-region of the northeastern Chukchi Sea during the open-water season. Continental Shelf Research 67:116-126. http://dx.doi.org/10.1016/j.csr.2013.04.020

Arrigo, K.R., and van Dijken, G.L. 2015. Continued increases in Arctic Ocean primary production. Progress in Oceanography 136:60-70. http://dx.doi.org/10.1016/j.pocean.2015.05.002

Arrigo, K.R., van Dijken, G., and Pabi, S. 2008. Impact of a shrinking Arctic ice cover on marine primary production. Geophysical Research Letters 35, L19603. http://dx.doi.org/10.1029/2008GL035028

Ashjian, C.J., Braund, S.R., Campbell, R.G., George, J.C., Kruse, J., Maslowski, W., Moore, S.E., et al. 2010. Climate variability, oceanography, bowhead whale distribution, and Iñupiat subsistence whaling near Barrow, Alaska. Arctic 63(2):179-194.

http://dx.doi.org/10.14430/arctic973

Azzara, A.J., Wang, H., and Rutherford, D. 2015. A 10-year projection of maritime activity in the U.S. Arctic region. Washington, D.C.: The International Council on Clean Transportation. 73 p.

Berline, L., Spitz, Y.H., Ashjian, C.J., Campbell, R.G., Maslowski, W., and Moore, S.E. 2008. Euphausiid transport in the western Arctic Ocean. Marine Ecology Progress Series 360:163-178. http://dx.doi.org/10.3354/meps07387

Bluhm, B.A., and Gradinger, R. 2008. Regional variability in food availability for Arctic marine mammals. Ecological Applications 18 (Supp. 2):S77-S96. http://dx.doi.org/10.1890/06-0562.1

Bluhm, B.A., Coyle, K.O., Konar, B., and Highsmith, R. 2007. High gray whale relative abundances associated with an oceanographic front in the south-central Chukchi Sea. Deep Sea Research Part II: Topical Studies in Oceanography 54(2326):2919-2933. http://dx.doi.org/10.1016/j.dsr2.2007.08.015

Bockstoce, J.R., and Burns, J.J. 1993. Commercial whaling in the North Pacific sector. Chapter 14. In: Burns, J.J., Montague, J.J., and Cowles, C.J., eds. The bowhead whale. Special Publication Number 2. Moss Landing, California: The Society for Marine Mammalogy. 563-577.

Brower, A.A., Ferguson, M.S., Schonberg, S.V., Jewett, S.C., and Clarke, J.T. in press. Gray whale distribution relative to benthic biomass and abundance: Northeastern Chukchi Sea 2009-2012. Deep-Sea Research.

Buckland, S.T., Anderson, D.R., Burnham, K.P., Laake, J.L., Borchers, D.L., and Thomas, L. 2001. Introduction to distance sampling: Estimating abundance of biological populations. Oxford: Oxford University Press.
Calambokidis, J., Darling, J.D., Deecke, V., Gearin, P., Gosho, M., Megill, W., Tomback, C.M., Goley, D., Toropova, C., and Gisborne, B. 2002. Abundance, range and movements of a feeding aggregation of gray whales (Eschrichtius robustus) from California to southeastern Alaska in 1998. Journal of Cetacean Research and Management 4(3):267-276.

Calenge, C. 2006. The package "adehabitat" for the R software: A tool for the analysis of space and habitat use by animals. Ecological Modeling 197(3-4):516-519. http://dx.doi.org/10.1016/j.ecolmodel.2006.03.017

- 2011. Exploratory analysis of the habitat selection by the wildlife in R: The adehabitatHS package.

https://cran.r-project.org/web/packages/adehabitatHS/ vignettes/adehabitatHS.pdf

Citta, J.J., Quakenbush, L.T., George, J.C., Small, R.J., HeideJorgensen, M.P., Brower, H., Adams, B., and Brower, L. 2012. Winter movements of bowhead whales (Balaena mysticetus) in the Bering Sea. Arctic 65(1):13-34.

http://dx.doi.org/10.14430/arctic4162

Citta, J.J., Quakenbush, L.T., Okkonen, S.R., Druckenmiller, M.L., Maslowski, W., Clement-Kinney, J., George, J.C., et al. 2015. Ecological characteristics of core-use areas used by BeringChukchi-Beaufort (BCB) bowhead whales, 2006-2012. Progress in Oceanography 136:201-222.

http://dx.doi.org/10.1016/j.pocean.2014.08.012

Clarke, J.T., Moore, S.E., and Ljungblad, D.K. 1989. Observations on gray whale (Eschrichtius robustus) utilization patterns in the northeastern Chukchi Sea, July-October 1982-1987. Canadian Journal of Zoology 67(11):2646-2654.

http://dx.doi.org/10.1139/z89-374

Clarke, J.T., Ferguson, M.C., Christman, C.L., Grassia, S.L., Brower, A.A., and Morse, L.J. 2011. Chukchi Offshore Monitoring in Drilling Area (COMIDA) distribution and relative abundance of marine mammals: Aerial surveys. Final Report, OCS Study BOEMRE 2011-06. Seattle, Washington: National Marine Mammal Laboratory, Alaska Fisheries Science Center, NMFS, NOAA.

http:/www.afsc.noaa.gov/nmml/PDF/COMIDA-2008-2010Report.pdf

Clarke, J.T., Christman, C.L., Brower, A.A., and Ferguson, M.C. 2012. Distribution and relative abundance of marine mammals in the Alaskan Chukchi and Beaufort Seas, 2011. Annual Report, OCS Study BOEM 2012-009. Seattle, Washington: National Marine Mammal Laboratory, Alaska Fisheries Science Center, NMFS, NOAA.

https://www.afsc.noaa.gov/nmml/PDF/COMIDA-2011Report.pdf

Clarke, J., Stafford, K., Moore, S.E., Rone, B., Aerts, L., and Crance, J. 2013a. Subarctic cetaceans in the southern Chukchi Sea: Evidence of recovery or response to a changing ecosystem. Oceanography 26(4):136-149.

http://dx.doi.org/10.5670/oceanog.2013.81 
Clarke, J.T., Christman, C.L., Brower, A.A., and Ferguson, M.C. 2013b. Distribution and relative abundance of marine mammals in the northeastern Chukchi and western Beaufort Seas, 2012. Annual Report, OCS Study BOEM 2013-00117. Seattle, Washington: National Marine Mammal Laboratory, Alaska Fisheries Science Center, NMFS, NOAA. http://www.afsc.noaa.gov/nmml/PDF/COMIDA-2012-Report. pdf

Clarke, J.T., Brower, A.A., Christman, C.L., and Ferguson, M.C. 2014. Distribution and relative abundance of marine mammals in the eastern Chukchi and western Beaufort Seas, 2013. Annual Report, OCS Study BOEM 2014-018. Seattle, Washington: National Marine Mammal Laboratory, Alaska Fisheries Science Center, NMFS, NOAA.

http://www.afsc.noaa.gov/nmml/PDF/ASAMM-2013-Report. pdf

Clarke, J.T., Brower, A.A., Ferguson, M.C., Kennedy, A.S., and Willoughby, A.L. 2015. Distribution and relative abundance of marine mammals in the eastern Chukchi and western Beaufort Seas, 2014. Annual Report, OCS Study BOEM 2015-040. Seattle, Washington: National Marine Mammal Laboratory, Alaska Fisheries Science Center, NMFS, NOAA.

http://www.afsc.noaa.gov/nmml/PDF/2014_ASAMM FinalAnnualReport_19october15_clean.pdf

Cohen, J., Screen, J.A., Furtado, J.C., Barlow, M., Whittleston, D., Coumou, D., Francis, J., Dethloff, K., Entekhabi, D., Overland, J., and Jones, J. 2014. Recent Arctic amplification and extreme mid-latitude weather. Nature Geoscience 7:627-637. http://dx.doi.org/10.1038/ngeo2234

Coyle, K.O., Bluhm, B., Konar, B., Blanchard, A., and Highsmith, R.C. 2007. Amphipod prey of gray whales in the northern Bering Sea: Comparison of biomass and distribution between the 1980s and 2002-2003. Deep Sea Research II 54(2326):2906-2918.

http://dx.doi.org/10.1016/j.dsr2.2007.08.026

Dahlheim, M., Bray, T., and Braham, H. 1980. Vessel survey for bowhead whales in the Bering and Chukchi Seas, June-July 1978. Marine Fisheries Review 42(9-10):51-57.

Delarue, J., Laurinolli, M., and Martin, B. 2009. Bowhead whale (Balaena mysticetus) songs in the Chukchi Sea between October 2007 and May 2008. Journal of the Acoustical Society of America 126(6):3319-3328.

http://dx.doi.org/10.1121/1.3257201

Derocher, A.E., Lunn, N.J., and Stirling, I. 2004. Polar bears in a warming climate. Integrative and Comparative Biology 44(2):163-176. http://dx.doi.org/10.1093/icb/44.2.163

Durban, J.W., Weller, D.W., Lang, A.R., and Perryman, W.L. in press. Estimating gray whale abundance from shore-based counts using a multilevel Bayesian model. Journal of Cetacean Research and Management.
Ferguson, M.C., and Clarke, J.T. 2013. Estimates of detection probability for BWASP bowhead whale, gray whale, and beluga sightings collected from Twin Otter and Aero Commander aircraft, 1989 to 2007 and 2008 to 2011. U.S. Department of Commerce, NOAA Technical Memorandum NMFSAFSC-261. 52 p.

http://www.afsc.noaa.gov/Publications/techmemos.htm

Ferguson, M.C., Waite, J.M., Curtice, C., Clarke, J.T., and Harrison, J. 2015. Biologically important areas for cetaceans within U.S. waters: Aleutian Islands and Bering Sea region. Aquatic Mammals 41(1):79-93.

http://dx.doi.org/10.1578/AM.41.1.2015.79

Frey, K.E., Moore, G.W.K., Cooper, L.W., and Grebmeier, J.M. 2015. Divergent patterns of recent sea ice cover across the Bering, Chukchi, and Beaufort Seas of the Pacific Arctic Region. Progress in Oceanography 136:32-49.

http://dx.doi.org/10.1016/j.pocean.2015.05.009

George, J.C., Clark, C., Carroll, G.M., and Ellison, W.T. 1989. Observations on the ice-breaking and ice navigation behavior of migrating bowhead whales (Balaena mysticetus) near Point Barrow, Alaska, spring 1985. Arctic 42(1):24-30. http://dx.doi.org/10.14430/arctic1636

Givens, G.H., Edmondson, S.L., George, J.C., Suydam, R., Charif, R.A., Rahaman, A., Hawthorne, D., Tudor, B., DeLong, R.A., and Clark, C.W. 2013. Estimate of 2011 abundance of the Bering-Chukchi-Beaufort Seas bowhead whale population. International Whaling Commission Paper SC/65a/BRG01. $30 \mathrm{p}$.

http://www.north-slope.org/assets/images/uploads/BH Abundance_Estimate_2011_givens_final.pdf

Gleason, J.S., and Rode, K.D. 2009. Polar bear distribution and habitat association reflect long-term changes in fall sea ice conditions in the Alaskan Beaufort Sea. Arctic 62(4):405-417. http://dx.doi.org/10.14430/arctic172

Grebmeier, J.M. 2012. Shifting patterns of life in the Pacific Arctic and Sub-Arctic Seas. Annual Review of Marine Science 4:63-78. http://dx.doi.org/10.1146/annurev-marine-120710-100926

Grebmeier, J.M., Cooper, L.W., Feder, H.M., and Sirenko, B.I. 2006. Ecosystem dynamics of the Pacific-influenced northern Bering and Chukchi Seas in the Amerasian Arctic. Progress in Oceanography 71(2-4):331-361.

http://dx.doi.org/10.1016/j.pocean.2006.10.001

Grebmeier, J.M., Bluhm, B.A., Cooper, L.W., Danielson, S.L., Arrigo, K.R., Blanchard, A.L., Clarke, J.T., et al. 2015. Ecosystem characteristics and processes facilitating persistent macrobenthic biomass hotspots and associated benthivory in the Pacific Arctic. Progress in Oceanography 136:92-114. http://dx.doi.org/10.1016/j.pocean.2015.05.006

Hannay, D.E., Delarue, J., Mouy, X., Martin, B.S., Leary, D., Oswald, J.N., and Vallarta, J. 2013. Marine mammal acoustic detections in the northeastern Chukchi Sea, September 2007-July 2011. Continental Shelf Research 67:127-146. http://dx.doi.org/10.1016/j.csr.2013.07.009 
Harwood, L.A., Auld, J., Joynt, A., and Moore, S.E. 2010. Distribution of bowhead whales in the SE Beaufort Sea during late summer, 2007-2009. Fisheries and Oceans Canada, Canadian Science Advisory Secretariat Research Document 2009/111. 22 p.

Jakobsson, M., Macnab, R., Mayer, L., Anderson, R., Edwards, M., Hatzky, J., Schenke, H.W., and Johnson, P. 2008. An improved bathymetric portrayal of the Arctic Ocean: Implications for ocean modeling and geological, geophysical and oceanographic analyses. Geophysical Research Letters 35, L07602. http://dx.doi.org/10.1029/2008GL033520

Jay, C.V., Fischbach, A.S., and Kochnev, A.A. 2012. Walrus areas of use in the Chukchi Sea during sparse sea ice cover. Marine Ecology Progress Series 468:1 - 13. http://dx.doi.org/10.3354/meps10057

Jeffries, M.O., Overland, J.E., and Perovich, D.K. 2013. The Arctic shifts to a new normal. Physics Today 66(10):35-40.

http://dx.doi.org/10.1063/PT.3.2147

Johannessen, O.M., and Miles, M.W. 2011. Critical vulnerabilities of marine and sea ice-based ecosystems in the High Arctic. Regional Environmental Change 11(Suppl. 1):S239-S248. http://dx.doi.org/10.1007/s10113-010-0186-5

KCS (Kovach Computing Services). 2012. Oriana Version 4.01. Anglesey, Wales: KCS. http://www.kovcomp.com

Kovacs, K.M., Lydersen, C., Overland, J.E., and Moore, S.E. 2011. Impacts of changing sea-ice conditions on Arctic marine mammals. Marine Biodiversity 41(1):181 - 194. http://dx.doi.org/10.1007/s12526-010-0061-0

Kuletz, K.J., Ferguson, M.C., Hurley, B., Gall, A.E., Labunski, E.A., and Morgan, T.C. 2015. Seasonal spatial patterns in seabird and marine mammal distribution in the eastern Chukchi and western Beaufort Seas: Identifying biologically important pelagic areas. Progress in Oceanography 136:175-200. http://dx.doi.org/10.1016/j.pocean.2015.05.012

Kwok, R., and Rothrock, D.A. 2009. Decline in Arctic sea ice thickness from submarine and ICESat records: 1958-2008. Geophysical Research Letters 36, L15501. http://dx.doi.org/10.1029/2009GL039035

Kwok, R., and Untersteiner, N. 2011. The thinning of Arctic sea ice. Physics Today 64(4):36-41. http://dx.doi.org/10.1063/1.3580491

Laake, J.L., Punt, A.E., Hobbs, R., Ferguson, M., Rugh, D., and Breiwick, J. 2012. Gray whale southbound migration surveys 1967-2006: An integrated re-analysis. Journal of Cetacean Research and Management 12(3):287-306.

Laidre, K.L., Stirling, I., Lowry, L.F., Wiig, O., Heide-Jørgensen, M.P., and Ferguson, S.H. 2008. Quantifying the sensitivity of Arctic marine mammals to climate-induced habitat change. Ecological Applications 18(Supp. 2):S97-S125. http://dx.doi.org/10.1890/06-0546.1

Laidre, K.L., Stern, H., Kovacs, K.M., Lowry, L., Moore, S.E., Regehr, E.V., Ferguson, S.H., et al. 2015. Arctic marine mammal population status, sea ice habitat loss, and conservation recommendations for the 21st century. Conservation Biology 29(3):724-737.

http://dx.doi.org/10.1111/cobi.12474
Maloney, E.S. 2006. Chapman piloting \& seamanship, $65^{\text {th }}$ ed. New York: Sterling Publishing Company, Inc.

Manly, B.F.J., McDonald, L.L., Thomas, D.L., McDonald, T.L., and Erickson, W.P. 2002. Resource selection by animals: Statistical design and analysis for field studies, $2^{\text {nd }}$ ed. New York: Kluwer Academic Publishers. http://dx.doi.org/10.1007/0-306-48151-0

Miller, R.V., Rugh, D.J., and Johnson, J.H. 1986. The distribution of bowhead whales, Balaena mysticetus, in the Chukchi Sea. Marine Mammal Science 2(3):214-222. http://dx.doi.org/10.1111/j.1748-7692.1986.tb00041.x

Minerals Management Service. 2008. MMS Chukchi Sea lease sale 193 breaks energy records with $\$ 2.6$ billion in high bids. Press Release \#3777, 6 February 2008.

http://www.boem.gov/boem-newsroom/press-releases/2008/ press0206.aspx

Monnett, C., and Treacy, S.D. 2005. Aerial surveys of endangered whales in the Beaufort Sea, fall 2002-2004. OCS Study MMS 2005-037. Anchorage: U.S. Department of the Interior, Minerals Management Service, Alaska OCS Region. 153 p. http://www.boem.gov/

Moore, S.E. 1992. Summer records of bowhead whales in the northeastern Chukchi Sea. Arctic 45(4):398-400. http://dx.doi.org/10.14430/arctic1419

- 2000. Variability of cetacean distribution and habitat selection in the Alaskan Arctic, autumn 1982-91. Arctic 53(4):448-460.

http://dx.doi.org/10.14430/arctic874

Moore, S.E., and Clarke, J.T. 1990. Distribution, abundance and behavior of endangered whales in the Alaskan Chukchi and western Beaufort Sea, 1989. NTIS Report No. PB91105494. Report by SEACO/Science Applications International Corporation to the U.S. Minerals Management Service, Alaska OCS Region. Springfield, Virginia: National Technical Information Service.

. 1991. Aerial surveys of endangered whales in the Alaskan Chukchi and western Beaufort Seas, 1990: Final field report. OCS Study MMS 91-0017. Final field report prepared by SAIC, Maritime Services Division for U.S. Minerals Management Service, Alaska OCS Region. 96 p.

- 1992. Patterns of bowhead whale distribution and abundance near Barrow, Alaska, in fall 1982-1989. Marine Mammal Science 8(1):27-36.

http://dx.doi.org/10.1111/j.1748-7692.1992.tb00122.x

Moore, S.E., and Huntington, H.P. 2008. Arctic marine mammals and climate change: Impacts and resilience. Ecological Applications 18(Supp. 2):S157-S165.

http://dx.doi.org/10.1890/06-0571.1

Moore, S.E., and Laidre, K.L. 2006. Trends in sea ice cover within habitats used by bowhead whales in the western Arctic. Ecological Applications 16(3):932-944. http://dx.doi.org/10.1890/1051-0761(2006)016[0932:TISICW]2 .0.CO;2

Moore, S.E., and Reeves, R.R. 1993. Distribution and movement. In: Burns, J.J., Montague, J.J., and Cowles, C.J., eds. The bowhead whale. Special Publication Number 2. Lawrence, Kansas: The Society for Marine Mammalogy. 313-386. 
Moore, S.E., DeMaster, D.P., and Dayton, P.K. 2000. Cetacean habitat selection in the Alaskan Arctic during summer and autumn. Arctic 53(4):432-447.

http://dx.doi.org/10.14430/arctic873

Moore, S.E., Grebmeier, J.M., and Davies, J.R. 2003. Gray whale distribution relative to forage habitat in the northern Bering Sea: Current conditions and retrospective summary. Canadian Journal of Zoology 81(4):734-742.

http://dx.doi.org/10.1139/z03-043

Moore, S.E., Wynne, K.M., Kinney, J.C., and Grebmeier, J.M. 2007. Gray whale occurrence and forage southeast of Kodiak Island, Alaska. Marine Mammal Science 23(2):419-428. http://dx.doi.org/10.1111/j.1748-7692.2007.00102.x

Moore, S.E., Stafford, K.M., and Munger, L.M. 2010. Acoustic and visual surveys for bowhead whales in the western Beaufort and far northeastern Chukchi Seas. Deep-Sea Research Part II 57(1-2):153-157.

http://dx.doi.org/10.1016/j.dsr2.2009.08.013

Quakenbush, L.T., Citta, J.J., George, J.C., Small, R.P., and HeideJørgensen, M.P. 2010. Fall and winter movements of bowhead whales (Balaena mysticetus) in the Chukchi Sea and within a potential petroleum development area. Arctic 63(3):289-307. http://dx.doi.org/10.14430/arctic1493

Quakenbush, L.T., Small, R.J., and Citta, J.J. 2013. Satellite tracking of bowhead whales: Movements and analysis from 2006 to 2012. OCS Study BOEM 2013-01110. Anchorage: U.S. Dept. of the Interior, Bureau of Ocean Energy Management, Alaska OCS Region. 60 p. + appendices.

R Core Team. 2015. R: A language and environment for statistical computing. Vienna, Austria: R Foundation for Statistical Computing. http://www.R-project.org/.

Rode, K.D., Regehr, E.V., Douglas, D.C., Durner, G., Derocher, A.E., Thiemann, G.W., and Budge, S.M. 2013. Variation in the response of an Arctic top predator experiencing habitat loss: Feeding and reproductive ecology of two polar bear populations. Global Change Biology 20(1):76-88. http://dx.doi.org/10.1111/gcb.12339

Rugh, D.J., Muto, M.M., Moore, S.E., and DeMaster, D.P. 1999. Status review of the Eastern North Pacific stock of gray whales. NOAA Technical Memorandum NMFS-AFSC-103. http://www.afsc.noaa.gov/Publications/techmemos.htm

Rugh, D.J., Shelden, K.E.W., and Schulman-Janiger, A. 2001. Timing of the gray whale southbound migration. Journal of Cetacean Research and Management 3(1):31-39.

Rugh, D., Breiwick, J., Hobbs, R., Shelden, K., and Muto, M. 2008. Eastern North Pacific gray whale abundance in the winter of 2006-2007. Paper SC/60/BRG6 presented to the IWC Scientific Committee, May 2008.

Schonberg, S.V., Clarke, J.T., and Dunton, K.H. 2014. Distribution, abundance, biomass and diversity of benthic infauna in the Northeast Chukchi Sea, Alaska: Relation to environmental variables and marine mammals. Deep-Sea Research Part II 102:144-163.

http://dx.doi.org/10.1016/j.dsr2.2013.11.004
Stroeve, J., Holland, M.M., Meier, W., Scambos, T., and Serreze, M. 2007. Arctic sea ice decline: Faster than forecast. Geophysical Research Letters 34, L09501. http://dx.doi.org/10.1029/2007GL029703

Thomas, T., Koski, W.R., and Ireland, D.S. 2010. Chukchi Sea nearshore aerial survey (Chapter 4) In: Funk, D.W., Ireland, D.S., Rodrigues, R., and Koski, W.R., eds. Joint Monitoring Program in the Chukchi and Beaufort Seas, open water seasons, 2006-2008. Final Report P1050-3. Report from LGL Alaska Research Associates, Inc., LGL Ltd., Greeneridge Sciences, Inc., and JASCO Research, Ltd., for Shell Offshore, Inc. and Other Industry Contributors, and National Marine Fisheries Service, U.S. Fish and Wildlife Service. 42 p.

http://www.nmfs.noaa.gov/pr/permits/incidental/oilgas/2006 -2008_final_jmp_comprpt.pdf

U.S. DOI (U.S. Department of the Interior). 2011. Chukchi Sea Planning Area, Oil and Gas Lease Sale 193 in the Chukchi Sea, Alaska: Final supplemental environmental impact statement. OCS EIS/EA BOEMRE 2011-041. Anchorage: Bureau of Ocean Energy Management.

http://www. Energy Management, Regulation and Enforcement, Alaska OCS Region. boem.gov/ak193/

- 2015. Chukchi Sea Outer Continental Shelf Oil and Gas Lease Sale 193: Record of Decision. Washington, D.C.: U.S. Department of the Interior.

http://www.boem.gov/ak193/

Weingartner, T., Aagaard, K., Woodgate, R., Danielson, S., Sasaki, Y., and Cavalieri, D. 2005. Circulation on the north central Chukchi Sea shelf. Deep-Sea Research Part II 52(2426):3150-3174.

http://dx.doi.org/10.1016/j.dsr2.2005.10.015

Weingartner, T., Dobbins, E., Danielson, S., Winsor, P., Potter, R., and Statscewich, H. 2013. Hydrographic variability over the northeastern Chukchi Sea shelf in summer-fall 2008-2010. Continental Shelf Research 67:5-22.

http://dx.doi.org/10.1016/j.csr.2013.03.012

Wood, K.R., Bond, N.A., Danielson, S.L., Overland, J.E., Salo, S.A., Stabeno, P.J., and Whitefield, J. 2015. A decade of environmental change in the Pacific Arctic region. Progress in Oceanography 136:12-31.

http://dx.doi.org/10.1016/j.pocean.2015.05.005

Woodgate, R.A., Weingartner, T.J., and Lindsay, R. 2012. Observed increases in Bering Strait oceanic fluxes from the Pacific to the Arctic from 2001 to 2011 and their impacts on the Arctic Ocean water column. Geophysical Research Letters 39, L24603. http://dx.doi.org/10.1029/2012GL054092

Zeh, J.E., and Punt, A.E. 2004. Updated 1978-2001 abundance estimates and their correlations for the Bering-ChukchiBeaufort Seas stock of bowhead whales. Paper SC/56/BRG1 presented to the IWC Scientific Committee, May 2004. 